\title{
Article \\ Exploration and Investigation of High-Level Radon Medicinal Springs in the Crystalline Units: Lugicum
}

\author{
Viktor Goliáš ${ }^{1, *}$, Lenka Hájková ${ }^{1}$, Tomáš Lipanský ${ }^{2}$, Tomáš Černík ${ }^{1}$, Pavel Kohn ${ }^{1}$, Josef Ježek ${ }^{1}$ (D), \\ Radek Procházka ${ }^{3}$, Tadeusz A. Przylibski ${ }^{4}$ (D) Jiří Dohnal ${ }^{1}$, Ladislav Strnad ${ }^{1}$, Agata Kowalska ${ }^{4}$ (D), \\ Lidia Fijałkowska-Lichwa ${ }^{5}$ (D), Wojciech Miśta ${ }^{4}$ and Robert Nowakowski ${ }^{4}$
}

check for updates

Citation: Goliáš, V.; Hájková, L.; Lipanský, T.; Černík, T.; Kohn, P.; Ježek, J.; Procházka, R.; Przylibski, T.A.; Dohnal, J.; Strnad, L.; et al. Exploration and Investigation of High-Level Radon Medicinal Springs in the Crystalline Units: Lugicum. Water 2022, 14, 200. https://doi.org/ $10.3390 / w 14020200$

Academic Editor: Frédéric Huneau

Received: 30 November 2021

Accepted: 31 December 2021

Published: 11 January 2022

Publisher's Note: MDPI stays neutral with regard to jurisdictional claims in published maps and institutional affiliations.

Copyright: (C) 2022 by the authors. Licensee MDPI, Basel, Switzerland. This article is an open access article distributed under the terms and conditions of the Creative Commons Attribution (CC BY) license (https:// creativecommons.org/licenses/by/ $4.0 /)$.
1 Faculty of Science, Charles University, Albertov 6, 12843 Prague, Czech Republic; lehruskova@centrum.cz (L.H.); polodrat@gmail.com (T.Č.); pavelkohn@email.cz (P.K.); josef.jezek@natur.cuni.cz (J.J.); jiri.dohnal@natur.cuni.cz (J.D.); ladislav.strnad@natur.cuni.cz (L.S.)

2 Watersystem Company, Ke Klimentce 8, 15000 Prague, Czech Republic; tomas@watersystem.cz

3 Geopro Company, Lesní 1079, 25229 Dobrichovice, Czech Republic; choda@seznam.cz

4 Faculty of Geoengineering, Mining and Geology, Wrocław University of Science and Technology, Wybrzeże S. Wyspiańskiego 27, 50-370 Wroclaw, Poland; tadeusz.przylibski@pwr.edu.pl (T.A.P.); agata.kowalska@pwr.edu.pl (A.K.); misiek.kobi@wp.pl (W.M.); nowakowski1@wp.pl (R.N.)

5 Faculty of Civil Engineering, Wrocław University of Science and Technology, Wybrzeże S. Wyspiańskiego 27, 50-370 Wroclaw, Poland; lidia.fijalkowska@pwr.wroc.pl

* Correspondence: wiki@natur.cuni.cz; Tel.: +420-221-951-511

\begin{abstract}
Radioactive (radon) groundwaters are highly valued among mineral waters for their healing effects. Between 2005 and 2015, a large exploratory event for prospecting and documenting radon water springs took place in the crystalline area of Lugicum (Bohemian Massif) under CzechPolish cooperation. For these purposes, an exploration method was developed as a combination of GIS (ArcMap 9.1-10.2) area preparation followed by field radiohydrogeochemical mapping at a scale of 1:10,000. The gamma indication method was optimized and used for the selection of water samples. A total of 2354 water sources were examined. Radon activity concentrations were measured at 660 sources found throughout the territory. Of those, 111 sources exhibited ${ }^{222} \mathrm{Rn}$ activity above $1500 \mathrm{~Bq} / \mathrm{L}$ and, thus, were categorized as sources of mineral radioactive waters according to Czech legislation. The highest ${ }^{222} \mathrm{Rn}$ activity was found in the Michael spring near Nové Město pod Smrkem (up to $6237 \mathrm{~Bq} / \mathrm{L}^{222} \mathrm{Rn}$ ). Many discovered sources with high balneological potential are significant and, therefore, are quickly becoming popular among the public.
\end{abstract}

Keywords: groundwater; radon; ${ }^{222} \mathrm{Rn}$; mineral water; Bohemian Massif; Lugicum; exploration

\section{Introduction}

According to Sheen et al. [1], Rodriguez-Martinez et al. [2], and other authors, radon $\left({ }^{222} \mathrm{Rn}\right)$ in dwellings has been considered a risk factor for lung cancer since 1985 . The International Agency for Research on Cancer recognizes radon as a carcinogen [3]. However, it must be emphasized that modern research methods [4] discredit the conclusions of studies proving the harmful effect of radon on the basis of a linear no-threshold theory. This theory has been in crisis for a long time, as its verification for the low-dose region is impossible [5]. As György [6] highlights, radon has been used continuously in spa therapy since 1905, based on the radiation hormesis theory. The use of radon waters in balneotherapeutic treatments produces beneficial effects on patients' health $[7,8]$. These effects are very complex, as radon activates the immune system [9-11]. Thus, radon waters (waters rich in dissolved ${ }^{222} \mathrm{Rn}$ ) are highly valued in balneotherapy for their curative effect.

However, the subject of this study was not the ongoing scientific dispute on the application of radon waters in balneotherapeutic treatments in light of radiation hormesis theory. This aspect of radon occurrence in the environment, including groundwaters, has been continuously discussed at length, e.g., by Przylibski [8]. 
The authors emphasize, however, that in many countries, especially in Central Europe, radon waters are used for balneotherapeutic treatments in a variety of health and spa resorts. The largest number of places where radon waters or radon is present in the atmosphere of caves or mines and are used for medicinal purposes are found in Germany, Austria, Hungary, Czech Republic, Poland, Italy, France, Greece, Bulgaria, Romania, Russia, and outside of Europe also in the USA, China, Japan, and Chile [7,8,12-17]. All these countries have appropriate laws regulating the application of radon treatments. In the light of such widespread application of radon waters in balneotherapy, it is important to ensure that health and spa resorts have access to abundant resources of good quality groundwaters, especially with appropriate concentrations of ${ }^{222} \mathrm{Rn}$. With this aim in mind, it is necessary to conduct geological, geophysical, and hydrogeological research aimed at identifying and documenting the occurrence of radon waters.

The main goal of the present study was to propose an efficient method for prospecting and documenting radon-rich water springs. Moreover, the article presents the outcome of using this method in a Lugian area built of crystalline rocks.

The findings of the study are composed of the results from fieldwork and laboratory tests carried out over a period of 11 years in which more than 2300 springs and other groundwater manifestations were analyzed. The results of such a wide-ranging and detailed research may be interesting to geologists and hydrogeologists in Europe and other continents, where, particularly in crystalline-rock areas, radon waters occur and may be exploited.

This research was initiated by the main author of the article (V.G.). The authors carried out the study within the Lugian crystalline area lying in the northern part of the Czech Republic and in southwestern Poland. Joint field research work in border areas was facilitated by the Polish and Czech accession to the European Union and the signing of the Schengen Agreement by both of these countries.

\section{Research Area}

The Lugian geological unit (also known as the Sudetes or the Sudety Mountains) is a complex terrain with joint tectonometamorphic evolution. The Lugicum unit forms the northern block of the Bohemian Massif, part of the European Variscan orogeny. Typical of this unit are the intrusions of pre-Variscan granitoids with Cambro-Ordovician intrusive age, determined by U-Pb zircon dating in the range of 480-515 Ma [18,19]. These granitoids were later, in the Variscan cycle, metamorphosed to orthogneisses differing mainly in the degree of dynamic deformation (granitogneiss, augen gneiss, and leaf gneiss) at the time of continental subduction and later during the exhumation of these rocks [20]. The geochemistry of orthogneisses is comparable throughout the whole territory. The rocks have a granite-monzogranite composition, only around Kowary (East Krkonoše) and Świeradów-Zdrój (Jizera Mountains) are there more mafic and felsic varieties [21]. In addition to orthogneisses, the Lugian unit contains metasediments, older Neoproterozoic to Cambrian age (mica schists, quartzites, less frequent amphibolites, porphyroides, and others) in the Stronie group of the Orlice-Sněžník dome, the Velká Úpa group in the Krkonoše and the Jizera Mountains, as well as younger Silurian phyllites in the Poniklá group in the Krkonoše Mountains [22]. The later intrusion of Variscan granite into the Krkonoše-Jizera plutonic complex is very important. It forms a uniform glasses-shaped body in the Krkonoše and the Jizera Mountains composed of several types of granite. It starts with an intrusion of geochemically diverse S-type Tanvald granite (317 Ma), followed by I-types of Jizera (319 Ma) and Liberec (320 Ma) porphyric granites, with a differentiated body of equigranular Harrachov and Krkonoše granites (315 Ma) at the center of the pluton [23]. The granites of the Krkonoše-Jizera Pluton differ in their uranium and thorium contents [24], and they are related to different accessory mineral associations. Zircon is found in all the K-J Pluton granite types, but the calcium-alkaline suite contains allanite, while the Tanvald-type granite contains monazite $[25,26]$. A number of manifestations of the Variscan-age uranium mineralization are associated with both Lugian orthogneisses 
and Variscan granites, especially in exocontacts with metamorphites [27-30]. The increased concentration of radioactive elements, especially uranium, in these rocks is contemporarily reflected by the occurrence of radon-rich groundwater springs.

The whole area of interest represents a hydrogeological massif, clearly distinct from neighboring geological units. Due to the mosaic-like geological structure with diverse lithological formations, from granites to schists and locally present limestones or marbles, all of the three kinds of groundwaters (i.e., layer, fissure, and locally karst waters) are found in the Lugicum geological unit. In dominant mountain areas composed of several large and many minor mountain ranges with widely varying altitudes (400-1600 m a.s.l.), water circulation is mostly local, shallow, with flow directions varying from place to place, with prevailing short residence times. An occurrence of increased ${ }^{222} \mathrm{Rn}$ activity in spring water may indicate additional effects on groundwater circulation. A common feature of Lugian groundwaters is their generally low mineralization [31,32].

\section{Materials and Methods}

In the described geological unit, the sources of mineral radon waters were searched. The radioactivity level of $1500 \mathrm{~Bq} / \mathrm{L}^{222} \mathrm{Rn}$ was accepted as a positive result because this level is the threshold value for radon mineral waters according to Czech law [33]. In Poland, groundwaters with ${ }^{222} \mathrm{Rn}$ concentrations equal to or higher than $74 \mathrm{~Bq} / \mathrm{L}$ may be considered as curative on the basis of Polish law [34]. Threshold values have not been harmonized in the European Union and, in some cases, the differences among national regulations across the EU are quite significant.

Instead of systematical sampling of all water sources, a method called "gammaindicative" was developed and optimized. It is based on classical surface exploration using the radiohydrogeological methods [35] and influenced by the uranium deposit exploration methods [36] and radioactive element mapping [37].

\subsection{Preparation of the Claim Area}

The initial exploration steps were carried out through a review of available literature, focusing on geological and hydrogeological research [38-40] and primary sources on water radioactivity (cited below, in the description of claims). A database on drinking water (Czech National Nuclear Authority) proved to be useless because it was too sparse.

The key stage of the study was the preparation of the claims in a GIS environment (ESRI ArcMap 9.1-10.2) in the Křovák (JTSK) coordinate system using common principles described in [41,42]. Basic GIS layers were used for all of the claims: a 1:50,000 geological map (www.geology.cz) (accessed on 11 November 2021), a 1:50,000 topography information (www.inspire.cz) (accessed on 11 November 2021), and uranium survey anomalies at the local station [43]. Additionally, primary data on uranium anomalies [44,45] from the archives of the DIAMO state enterprise in Dolní Rožínka (Claim \#1) and Stráž pod Ralskem (Claims \#2-5) were also studied. Unsuccessfully, the study also tried a 1:50,000 radon risk index map for claim \#1 (www.geology.cz) (accessed on 11 November 2021). For the claims \#3-5, the authors digitized and rectified the uranium map from airborne gamma spectrometry [46] and also utilized the map of linear structures from remote sensing [47]. Interesting and perspective areas were determined through careful thought on the available mentioned layers. GIS outputs (layer composites) were printed for field use on the whole claim exploration in advance, because internet service was not available at the claims.

\subsection{Metrology}

The basic screening of the explored area was performed using sensitive field gamma dose rate meters (scintillometers) with $\mathrm{Na}$ (Tl) detectors of $ø 30 \times 20 \mathrm{~mm}$ (RFS-05 probes) and $ø 18.5 \times 30 \mathrm{~mm}$ (RS-107 probe), produced formerly by the ZMA Ostrov Company (Czechia) in 1975-1990 for uranium deposit exploration [48]. The largest advantage of the probes was their robustness and water-tightness. The individual probes RFS-05 and RS-107 were connected to RP-11 and RP-106 impulse frequency meters (integrators). Technologically, a 
more advanced RS-107 probe was calibrated to the uranium $2 \pi$ standard on the calibration facility at the DIAMO state enterprise in Stráž pod Ralskem (www.gammastandard.com) (accessed on 11 November 2021) by following the established procedures [49,50]. A comparative measurement of the probes' responses was conducted at the same surface location at the beginning of each exploratory action, and the sensitivities of the other probes were adjusted to account for the calibrated one (Figure 1). Probe sensitivities ranged from 0.33 to $0.55 \mathrm{imp} \mathrm{s}^{-1} \mathrm{nGy}^{-1} \mathrm{~h}^{-1}$. The analog integrator reading accuracy was better than $10 \%$ (1 sigma).

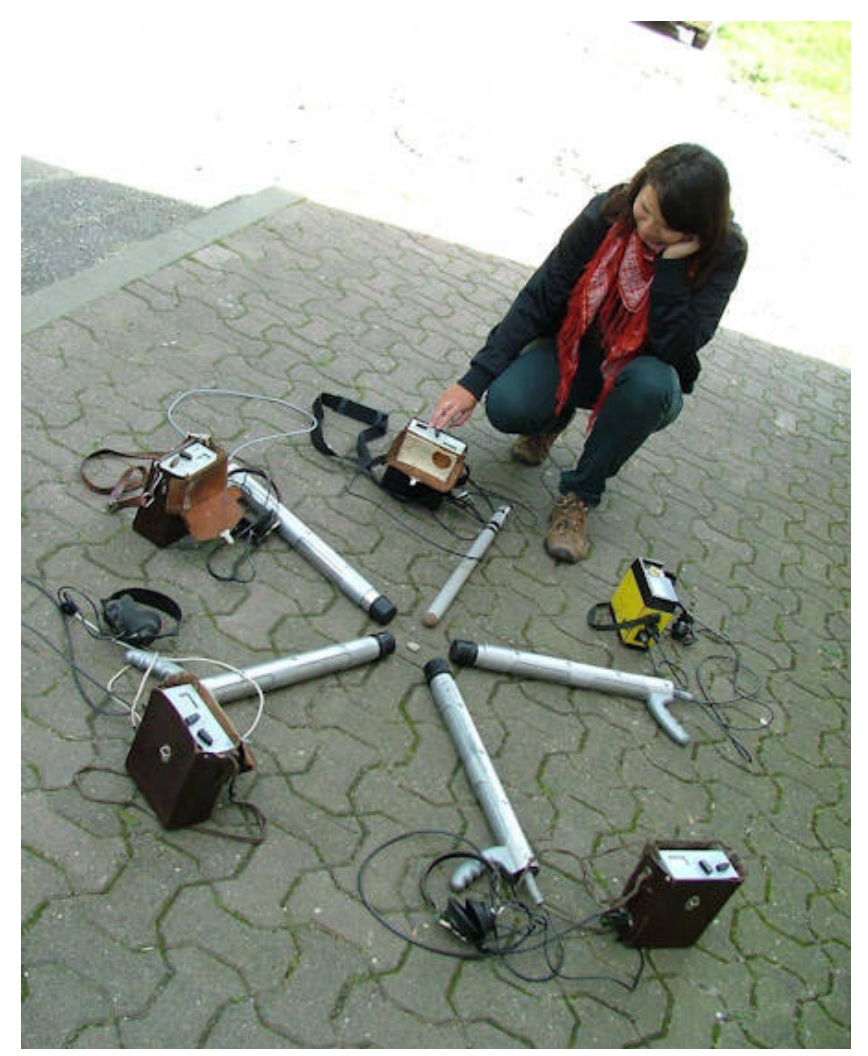

Figure 1. Comparative measurement of RP scintillometers at the field base in Lázně Libverda, Claim \#3. Photo by Zdeňka Petrová September 2010, with permission.

The basic method for the determination of radon activity in water was emanometry, which makes it possible to measure cloudy to muddy samples. A portable RP-25 emanometer (ZMA Ostrov, Czechia) with a $0.43 \mathrm{~L}$ ionization chamber in a circulation regime was used [51]. It can also be used directly to measure the spring radon activity on the site to guide technical work in the field. Air circulation in the degassing bottle $(0.75 \mathrm{~L})$ and ionization chamber circuit was performed for $4 \mathrm{~min}$, the total measurement time of one sample was approximately $10 \mathrm{~min}$. The highest number of samples measured in a single evening was 25 . Repeated measurements of ten subsequent samples of the same water showed 1 sigma of $12 \%$.

The LSC method in its most sensitive modification (e.g., the extraction method in $[52,53])$ was used to measure radon in the captured springs and other clear water samples. The LSC counter, TRIATHLER (Hidex, Turku, Finland), was used on the field base. Control analyses were measured on an ultra-low background liquid scintillation spectrometer $\alpha / \beta$ Quantulus 1220 (Perkin Elmer, Waltham, MA, USA) at the Wrocław University of Science and Technology. The accuracy of the LSC equipment was better than $1 \%$, depending on the count in their alpha channels.

A common set of standards was prepared for emanation and LSC methods of radon measurement by diluting the ${ }^{226}$ Ra standard EB-7 solution, supplied by the Czech Metrolog- 
ical Institute. Several series of comparative tests and links to the international laboratories were realized repeatedly.

The chemical compositions of the waters were measured at the Laboratories of the Geological Institutes (Charles University, Prague). Cations were determined by F-AAS (Varian 280, Crawley, UK) and ICP-OES (Agilent 5110, Santa Clara, CA, USA) methods, anions by liquid chromatography (Deionex HPLC, Sunnyvale, CA, USA), and microelements (including uranium) were determined by quadrupole ICP-MS (iCAP Q, Thermo Fischer, Waltham, MA, USA). Radium ( ${ }^{226} \mathrm{Ra}$ ) was determined by LSC on a Quantulus 1220 (Perkin Elmer, Waltham, MA, USA) or TRIATHLER (Hidex, Turku, Finland) instrument.

\subsection{Field Exploration Technique}

The area preparation was followed by field radiohydrogeochemical exploration at a scale of 1:10,000. The individual events quickly took the form of field mapping courses with high participation of enthusiastic students. The method gradually evolved and was optimized. Initially, an emanometer was carried along with the scintillometer to measure radon activity concentrations directly at the source. However, such a procedure proved to be very slow as one measurement took at least $10 \mathrm{~min}$. Therefore, based on experience, the method was optimized for the scintillometer only. It became one of the essential requisites.

The exploratory groups often consisted of two members: an experienced explorer and (perhaps) a novice. An experienced explorer could also go alone if (s)he attached a hoe to his/her backpack. The planning of the exploratory track was crucial. Discussion of among the whole group during the preceding evening at the field base resulted in a detailed survey area plan outlined in a 1:10,000 topographic map based on the prepared GIS printouts.

Each group had a scintillometer, a hoe, a waterproof board with a 1:10,000 map attached, a notebook with a pencil, a GPS receiver, a set of 5 bottles for taking samples $(0.5 \mathrm{~L}$ beer bottle with a patent closure), and a tin mug. All members wore all-terrain clothes and necessary rubber boots.

When passing through the terrain, the gamma dose rate indicated by the scintillometer was continuously observed through the attached headphones. All water manifestations were measured, both natural sources (i.e., springs, swamps, and surface leaks) as well as sources modified by human activity (i.e., wells, waterworks, and water reservoirs, where available). The hydrological situation was continuously updated on the map. Water manifestations without increased gamma dose rates were plotted only on the map using the code letter "N" for negative indications. GPS positioning would be too delaying. Their geographic coordinates were later (after the return from the whole field exploration event) digitized with a theoretical accuracy of approximately 10-20 m using a transparent grid of a $100 \times 100 \mathrm{~m}$ spatial resolution. The recorded negative indications were also important, as they confirmed a covered area.

Water stretches or manifestations with increased gamma dose rates (indicated) were examined in detail to find the place with the highest gamma dose rates, in any substrate (i.e., gravel, mud, water, and living plants), and at any probe depth, i.e., often in $>2 \pi$ geometry. There, the maximum value and nature of the substrate were recorded. Such a place was dug out to locate the inflow of water, which was subsequently sampled. Sample locations were plotted on the map with an attached (assigned) code (exploratory group/sample number) and were also recorded in the notebook containing the information regarding source code, position (description and GPS coordinates), type of manifestation (spring, wetland, well, etc.), flowrate estimation (L/s), maximum measured gamma dose rate in the water source, gamma dose rate of natural background in the $2 \pi$ geometry (i.e., flat surface and detector placed on ground), outside the water source (imp/s), bottle number, and sampling time. At different times, 1-5 exploratory groups operated in the field simultaneously. One group was able to responsibly explore an area of approximately $1 \mathrm{~km}^{2}$ per day.

The samples were measured on the field base after the return of the exploratory groups in the evening. The discovery of every new "positive" source ( $\left.>1500 \mathrm{~Bq} / \mathrm{L}^{222} \mathrm{Rn}\right)$ 
was always a cause for a small celebration and satisfactory for the successful field group. After radon measurement, $\mathrm{pH}$, Eh, and EC were additionally measured (HANNA Testers HI98121 and HI98129, Wensocket, RI, USA) in the same (de-emaned) sample.

According to the new results, the field survey for the next day was planned and directed. The revision group, composed of the most experienced workers and students, examined the identified places of interest and their surroundings in detail. The basic exploratory groups continued working in other areas.

At least four exploratory events lasting 7-9 days were realized on each claim, usually in the months of June and September in a given year. Thus, each claim was studied for approximately two years. In the first year, the objective was to identify the potential of the whole claim through a standard survey (including contacts with surrounding geological units such as granite and metasediments). In the second year, the standard survey was limited to yet unexplored claim parts only. The prospective places identified earlier were examined in detail. Some of those were technically altered to allow and ease further investigation into the possibility of using them as the mineral water sources.

The last activity on each claim was to sample the selected sources for chemical analysis. The samples were filtered through a $0.45 \mu \mathrm{m}$ membrane filter (Millipore, Burlington, MA, USA) using a vacuum apparatus (Sartorius, Göttingen, Germany). The cation sample was acidified by $\mathrm{HNO}_{3}$. The plastic bottles carrying water samples were stored temporarily in the fridge on the field base and then transported to the laboratory in Prague.

\subsection{Field Data Finalization}

The processing of individual claims in the form of diploma theses proved to be very successful. A selected student took part in the preparation of the areas in GIS and in all field events (while others interested were invited to take part as well). After each field event, (s)he digitized original field records from maps and notebooks, converted gamma dose rates measured from imp/s into $\mathrm{nGy} / \mathrm{h}$, and displayed newly acquired data in a GIS environment. (S)he then processed all data in his/her diploma thesis. In its creation, the student was inspired by the structure and approach of his/her predecessors. The defended diploma thesis was used not only for finalization but also for archiving of the acquired data.

\section{Results}

Since fresh flowing water is almost free of the short-lived ${ }^{222} \mathrm{Rn}$ gamma active progeny $\left({ }^{214} \mathrm{~Pb}\right.$ and $\left.{ }^{214} \mathrm{Bi}\right)$, its gamma activity may be assumed as close to zero. Thirteen-hour measurement of gamma activity of the fresh water by a scintillometer on a bottle sample demonstrated the age of the water to be 6 min (Figure 2). "Age of water" expresses the length of the radioactive equilibrium development between radon and its progeny from the virtual beginning (in the underground) to the time of outflow.

The background level of rocks' radioactivity plays a very important role in gamma measurement, because it is compared with the gamma dose rate of the water source. Based on a close average $(116 \mathrm{nGy} / \mathrm{h})$ and median $(120 \mathrm{nGy} / \mathrm{h})$ values combined with the information from a histogram, the observed background distribution was assumed to be normal. These values were almost double those off the Bohemian Massif average of $66 \mathrm{nGy} / \mathrm{h} \mathrm{[54]} \mathrm{and} \mathrm{reflect} \mathrm{an} \mathrm{increasing} \mathrm{content} \mathrm{of} \mathrm{natural} \mathrm{radionuclides} \mathrm{in} \mathrm{rocks} \mathrm{in} \mathrm{the}$ area explored. The lowest background value of $42 \mathrm{nGy} / \mathrm{h}$ was measured in metasediments (phyllites) in the vicinity of the orthogneiss body south of Janské Lázně. The highest value of $485 \mathrm{nGy} / \mathrm{h}$ was found on a differentiated Krkonoše granite, near the Josefka (PL1) spring, under a rock, i.e., in geometry $>2 \pi$ (both extreme values came from the Claim \#2). 


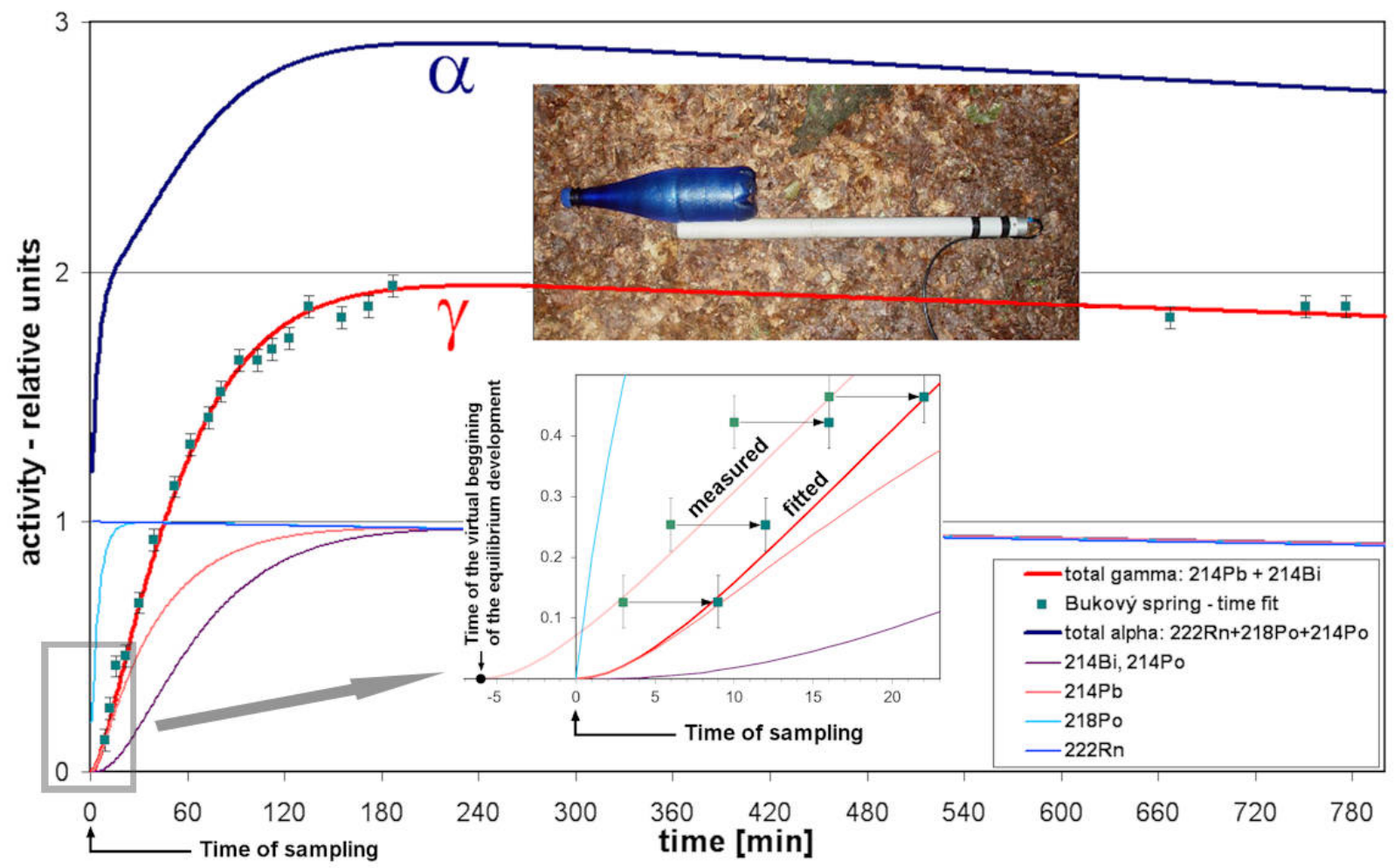

Figure 2. Ingrowth of gamma activity measured by scintillometer probe in contact with a $1 \mathrm{~L}$ bottle of the fresh radon water from Bukový spring (4.5 kBq/L ${ }^{222} \mathrm{Rn}$, Janské Lázně, Claim \#3, 17 June 2007). Natural background subtracted and both uncertainties combined. Time fit of measured data into a calculated curve of total gamma activity $\left({ }^{214} \mathrm{~Pb}+{ }^{214} \mathrm{Bi}\right)$ resulted in an effective water age of $6 \mathrm{~min}$. A similar experiment a year later showed the effective water age of only $3 \mathrm{~min}$.

Higher gamma dose rates were frequently detectable in real natural conditions just at the place of the water source. This additional gamma dose rate showed lognormal distribution with an average of 689 and median $501 \mathrm{nGy} / \mathrm{h}$, (with a maximum of $4665 \mathrm{nGy} / \mathrm{h}$ in water mosses, through a large volume of water from the abandoned water supply catchment in the Černá Studnice flowing, source TG3/16 in Claim \#5). In such (positive) cases, dissolved radon $\left({ }^{222} \mathrm{Rn}\right)$ activity concentration was also found.

Although the $x-y$ graph of the radon activity concentrations and gamma dose rates showed considerable variability (Figure 3a), their correlation was statistically significant (Pearson correlation coefficients of 0.627 and 0.582 for original and logarithmic data, respectively; Spearman coefficient of 0.636 with a $p$-value $<2.2 \times 10^{-16}$ ). The relation between the two variables can be approximated by linear regression through the origin. The square of the sample correlation was proposed as a measure analogous to the coefficient of determination for the no-intercept model $[55,56]$. In the present case, the square of the sample correlation was $R^{2}=0.393$. Figure $3 \mathrm{~b}$ documents that a closer relationship can be obtained after division of the whole data set in four environmental groups in respect to the substrate where the gamma dose rate was measured (except living plants, where the situation was very specific due to the low number of cases reported from the field). Higher correlations in the first three groups are in line with typical radon-progeny equilibrium levels that occur in these environments. Comparison of the slopes showed that the level of radioactive equilibrium increased generally in the direction from gravel through water and mud to plants. 


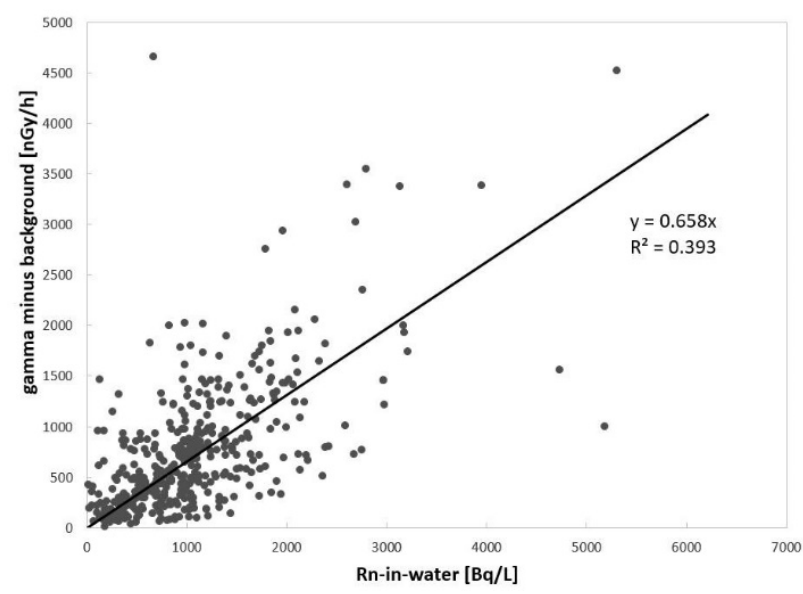

(a)

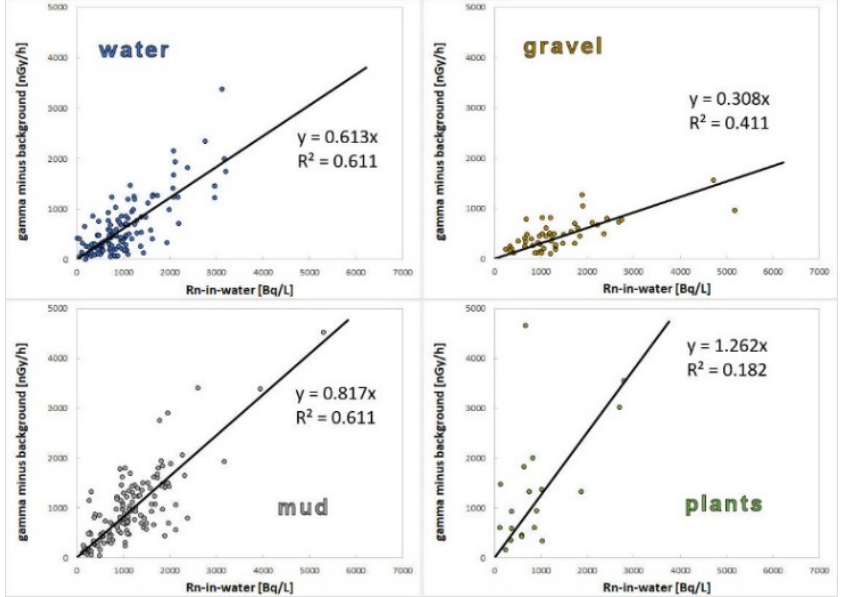

(b)

Figure 3. Relationship of the gamma dose rate-in-water and radon-in-water activity. Data from the whole Lugian area (a) divided into four environmental groups according to the substrate where the gamma dose rate was measured: water, gravel, mud, and living plants (b).

In the whole territory, 2354 water sources were measured (Figure 4), 1694 sources were classified as negative, while only 660 measurements of radon activity concentration in water were performed, of which only 111 sources exceeded $1500 \mathrm{~Bq} / \mathrm{L}^{222} \mathrm{Rn}$ to be qualified as the sources of radon mineral waters (Table 1).

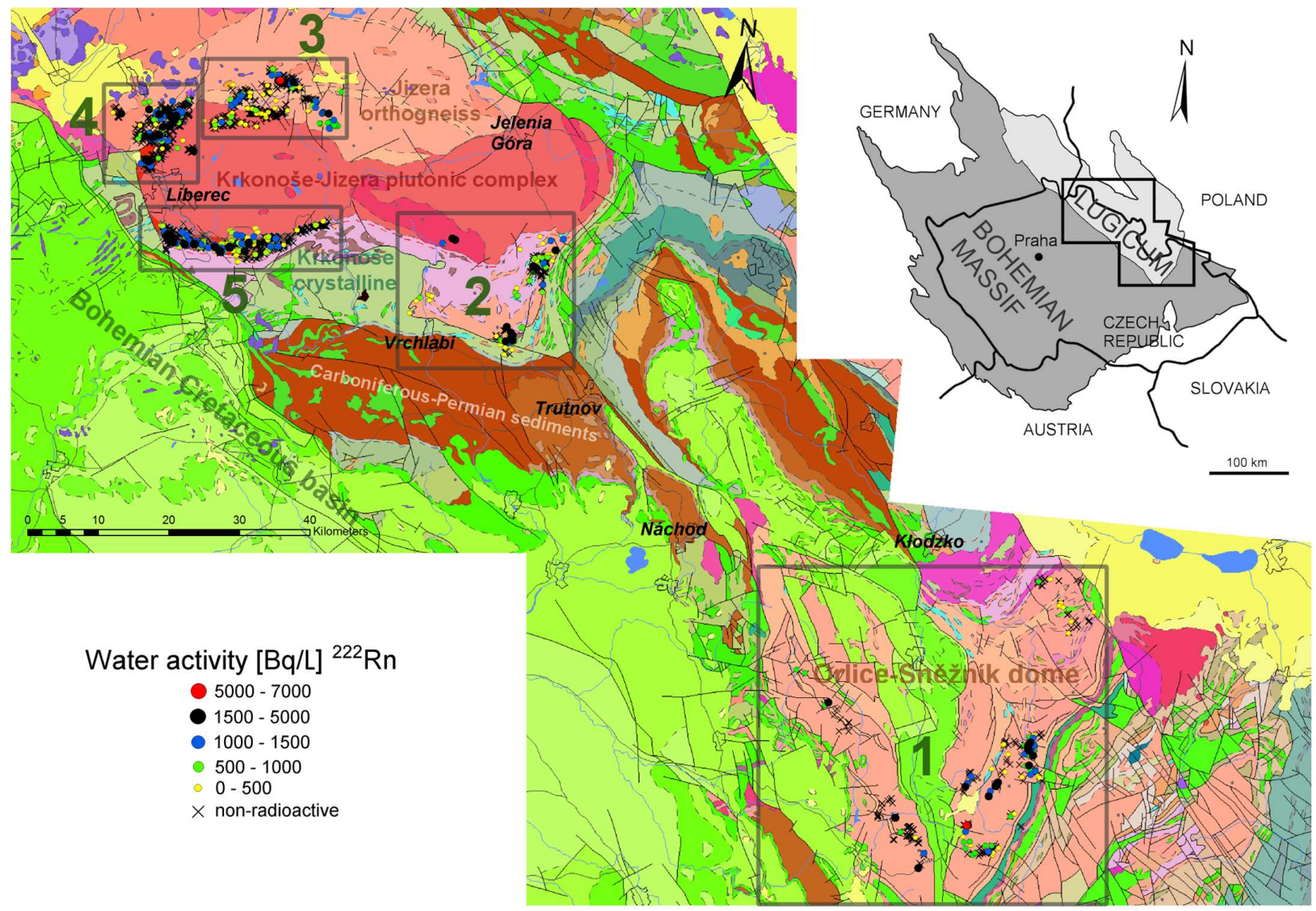

Figure 4. Lugicum: all data for the Rn-in-water activities measured in Claims \#1-5. GIS composite based on a geological map of 1:500,000 (www.geology.cz) (accessed on 11 November 2021). 
The results indicate that every twenty-first water source with radon activity $(4.7 \%)$ crossed the threshold level in the explored Lugian area. Sources of radon mineral water accounted for $16.7 \%$ of the total 660 sources with observed radon activity concentrations.

The distribution of values was lognormal but modified by the sampling method. The average was 923, and the median was $770 \mathrm{~Bq} / \mathrm{L}$. However, they did not express the average or median radon activity concentrations of the area's waters, as they were strongly influenced (increased) by the selective sampling method used (see Section 5).

The highest radon activity concentration reached $6215 \mathrm{~Bq} / \mathrm{L}$ in the Michael spring L3/6 near Nové Město p. Smrkem in Claim \#3. The cumulative frequencies for each claim and total are presented in Table 1. All data are available in the Supplementary Material S1.

A number of non-water-related gamma anomalies, which are called "dry gamma", were also found in the area explored. The most interesting of these was found on the Kokonín fault (Claim \#5), where inhabitants recently built two houses directly on the outcrop of a vein with uranium mineralization [30].

Most of the radioactive springs are bound to the Lugian orthogneiss created terrain, in Claims \#1-4. In the Variscan igneous rocks group, the Tanvald granite (Claims \#4 and \#5) is also a suitable rock as well as the differentiated Krkonoše granite in Claim \#2.

However, on the Variscan granitoids, which form a major part of the body of the Krkonoše-Jizera Pluton (i.e., on the Liberec and Jizera types), waters with significantly lower activity were found, although they were also extensively investigated in Claims \#2-5. The only positive measurement was at the Nežádoucí ("Undesirable”) spring CH3/27 (1244-1535 Bq/L, 3-6 L/min) in the vicinity of the Fojtka settlement (Claim \#3). The lowest activity waters were found in the metasediments surrounding all the claims. The highest and the only positive measurement was recorded at the Krmelec ("Feeder") spring JL-24 (877-1568 Bq/L, 1.4-7 L/min) flowing from quartzites, approximately a few hundred meters away from the orthogneiss body, north of the Janské Lázně (Claim \#2).

The basic characteristics of the selected top ten sources of Lugian area are presented in Table 2. From a physical point of view, the water found was generally cold, and its temperature depended on the altitude, was slightly acidic and mostly of high oxidation reduction potential. The temperature and flow rate of the sources changed slightly in time depending on the annual temperature change and precipitation. Heat waves made them slow while the springs were coldest in May and June.

These facts show that they were groundwaters of shallow circulation and contemporary infiltration. Usually, a negative correlation between flow rate and radon activity concentration variations were observed. Nevertheless, positive correlations were found in a few rare cases of certain important waters based on many observations.

From a chemical point of view, the waters were mostly lowly mineralized (up to $200 \mathrm{mg} / \mathrm{L}$ ) and of simple hydrochemical types (Table A1 in Appendix A). Some of these waters contained elevated uranium concentrations. Radon is an independent component. Radon-chloride waters, mostly of the $\mathrm{Na}-\mathrm{Ca}-\mathrm{Cl}$ type, with the total mineralization up to $1.5 \mathrm{~g} / \mathrm{L}$, were also found on Claims \#4 and \#5. These waters contained significantly elevated radium $\left({ }^{226} \mathrm{Ra}\right)$ activities. The chloride content correlated with the activity of radium and its chemical analogues, strontium, and barium. A microchemical curiosity was that in most of the investigated radioactive sources, the content of manganese predominated over iron.

Partial results of this research have been published before (see relevant citations below in the References section) or contributed to a comprehensive compendium [32] before the project was completed. The main and most important results of each claim are presented below. 
Table 1. Summarized data on the number of measured water outflows and cumulative numbers of objects exceeding the given radon activity in the whole Lugian area.

\begin{tabular}{|c|c|c|c|c|c|c|}
\hline Claim Statistics & Claim \#1 & Claim \#2 & Claim \#3 & Claim \#4 & Claim \#5 & Total \\
\hline Claim Name & Orlice-Sněžník Dome & East Krkonoše & $\begin{array}{l}\text { Lázně Liverda- } \\
\text { Świeradów-Zdrój }\end{array}$ & Chrastava-Bogatynia & Tanvald Graite & Lugicum \\
\hline Main Source Rock & Sněžník Othogneiss & $\begin{array}{c}\text { Krkonoše Othogneiss } \\
\text { (+Krkonoše Granite) }\end{array}$ & Jizera Othogneiss & $\begin{array}{l}\text { Jizera Othogneiss } \\
\text { (+Tanvald Granite) }\end{array}$ & TanvaldGranite & Orthogneiss(+Granites) \\
\hline Years of Exploration & 2005-2006 & 2008-2009 & 2010-2011 & 2012-2013 & 2014-2015 & 2005-2015 \\
\hline Sources measured in total & 349 & 271 & 570 & 510 & 654 & 2354 \\
\hline${ }^{222} \mathrm{Rn}$ activity determination & 122 & 120 & 155 & 120 & 143 & 660 \\
\hline Activity ${ }^{222} \mathrm{Rn}>500 \mathrm{~Bq} / \mathrm{L}$ & 89 & 54 & 86 & 101 & 107 & 437 \\
\hline Activity ${ }^{222} \mathrm{Rn}>1000 \mathrm{~Bq} / \mathrm{L}$ & 55 & 24 & 48 & 69 & 52 & 248 \\
\hline Activity ${ }^{222} \mathrm{Rn}>1500 \mathrm{~Bq} / \mathrm{L}$ & 26 & 12 & 23 & 29 & 21 & 111 \\
\hline Activity ${ }^{222} \mathrm{Rn}>2000 \mathrm{~Bq} / \mathrm{L}$ & 14 & 8 & 13 & 11 & 11 & 57 \\
\hline Activity ${ }^{222} \mathrm{Rn}>5000 \mathrm{~Bq} / \mathrm{L}$ & 1 & 0 & 1 & 0 & 0 & 2 \\
\hline
\end{tabular}

Table 2. Basic characteristics and parameters of the ten most important sources of radioactive mineral waters in the Lugian area.

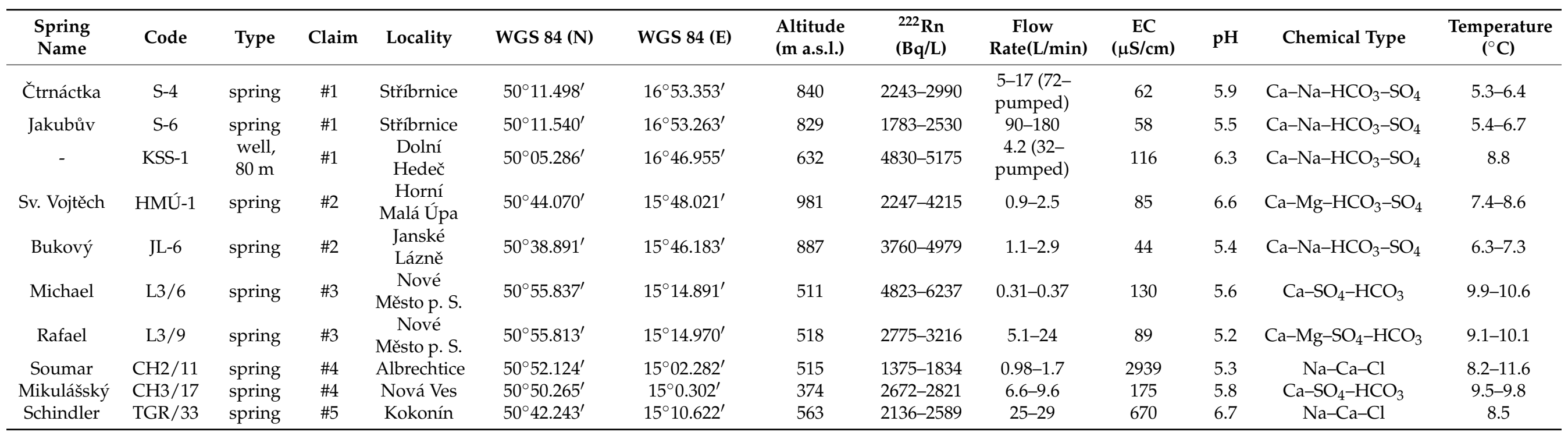




\subsection{Claim \#1-Orlice-Sněžník Dome}

On this claim is the Snežník orthogneiss, the only source rock. The orthogneiss dome is divided into two mirror halves, and between them is located Kłodzko graben, filled with Mesozoic (Cretaceous) sediments of up to $800 \mathrm{~m}$ in thickness [57] (Figure 5).

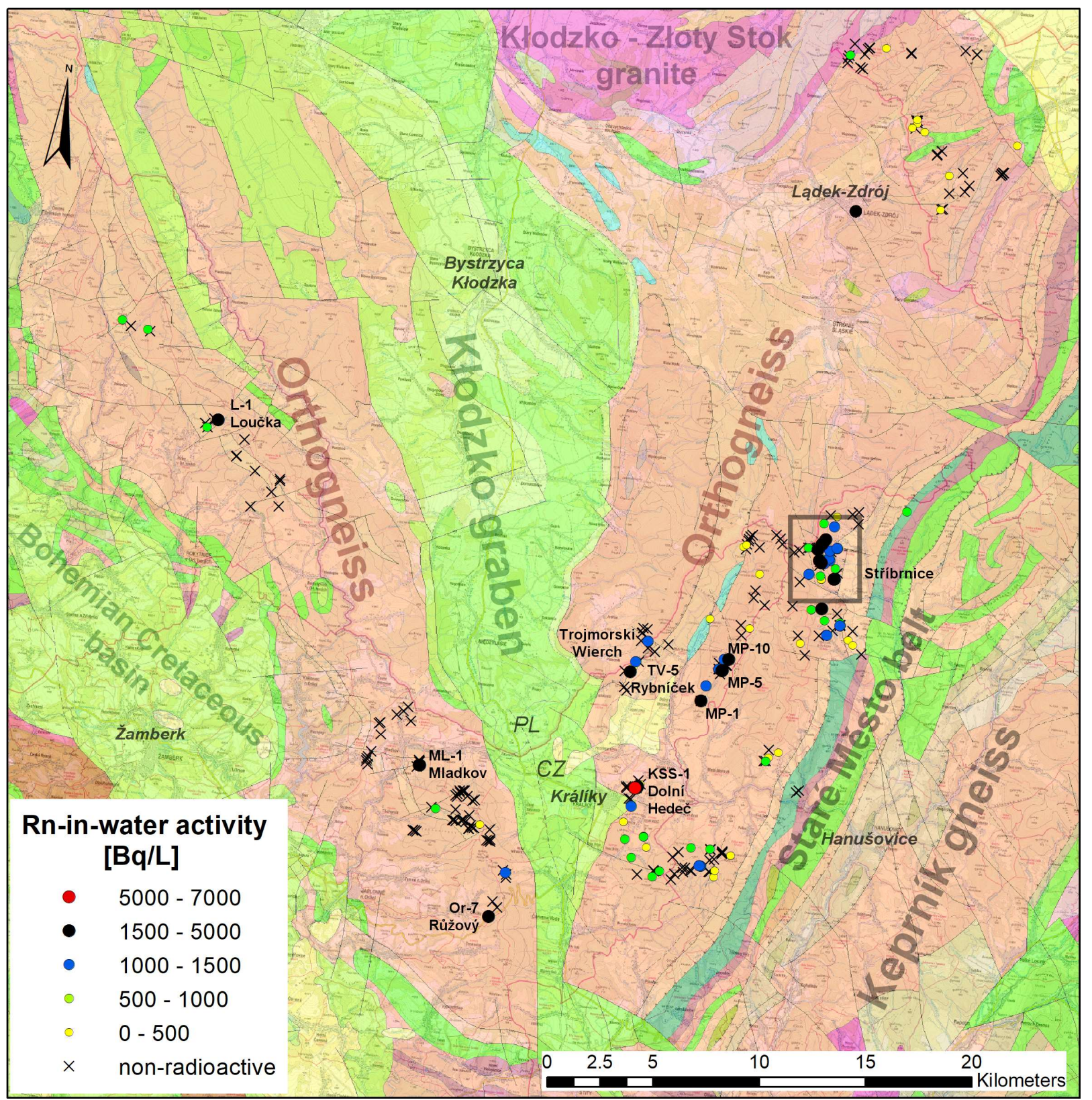

Figure 5. Radon-in-water activities in the Orlice-Sněžník dome, Claim \#1. GIS composite.

In the western part, a historically known spring is located at Mladkov [58]. The most active of the inflows had up to $1668 \mathrm{~Bq} / \mathrm{L}$ [59]; but since 2016, the captured water hardly reaches $1500 \mathrm{~Bq} / \mathrm{L}^{222} \mathrm{Rn}$ due to the interventions by the local municipality's faulty field collection system. Many other important sources were found in the eastern part of the dome [59]. The small cluster of four sources close to the village of Dolní Hedeč near Králíky town, straight on the edge of the Kłodzko graben is significant. Here, exists the most active source of the whole Claim \#1, overflowing borehole KSS-1 with an activity up to $5175 \mathrm{~Bq} / \mathrm{L}$ (Table 2). According to the preserved documentation, there is $10.5 \mathrm{~m}$ of Quaternary below which there is orthogneiss to a depth of $80 \mathrm{~m}$. The ranges of 39-50 and 
55-75 $\mathrm{m}$ are open for water. In the vicinity, there are three surface springs. One of them, the Opukový ("Calcareous Siltstone") spring Kr-4 (up to $2.4 \mathrm{kBq} / \mathrm{L}, 18 \mathrm{~L} / \mathrm{min}$ ), flows directly from the sediments.

The most important location is Střibrnice, with a large cluster of six springs (Figure 6). There exists the most important source of the whole Lugicum, Jakubův ("Jacob's") spring S-6 (Table 2), by its radiation flow (Rn activity concentration multiplied by the flow rate), which reaches up to $7.6 \mathrm{kBq} / \mathrm{s}$. It is really an outstanding spring of radon water (Figure 7). Not far from it, flows another significant spring S-4 Ctrnáctka ("Fourteen") (Table 2). Fortunately, a geophysical survey by the frequency method TURAM (1965, DIAMO archive, unpublished) was carried out in a small area during the uranium survey. There is a Kletno thrust (reverse fault) going through in the valley's axis; the conductive zone has a thickness of approximately $50 \mathrm{~m}$. From the thrust splays two normal faults that precisely control the positions of the radioactive springs (Figure 6). The Strribrnice springs flow on the main tourist route to Kralický Sněžník (the highest mountain in Moravia) and they are frequently visited.

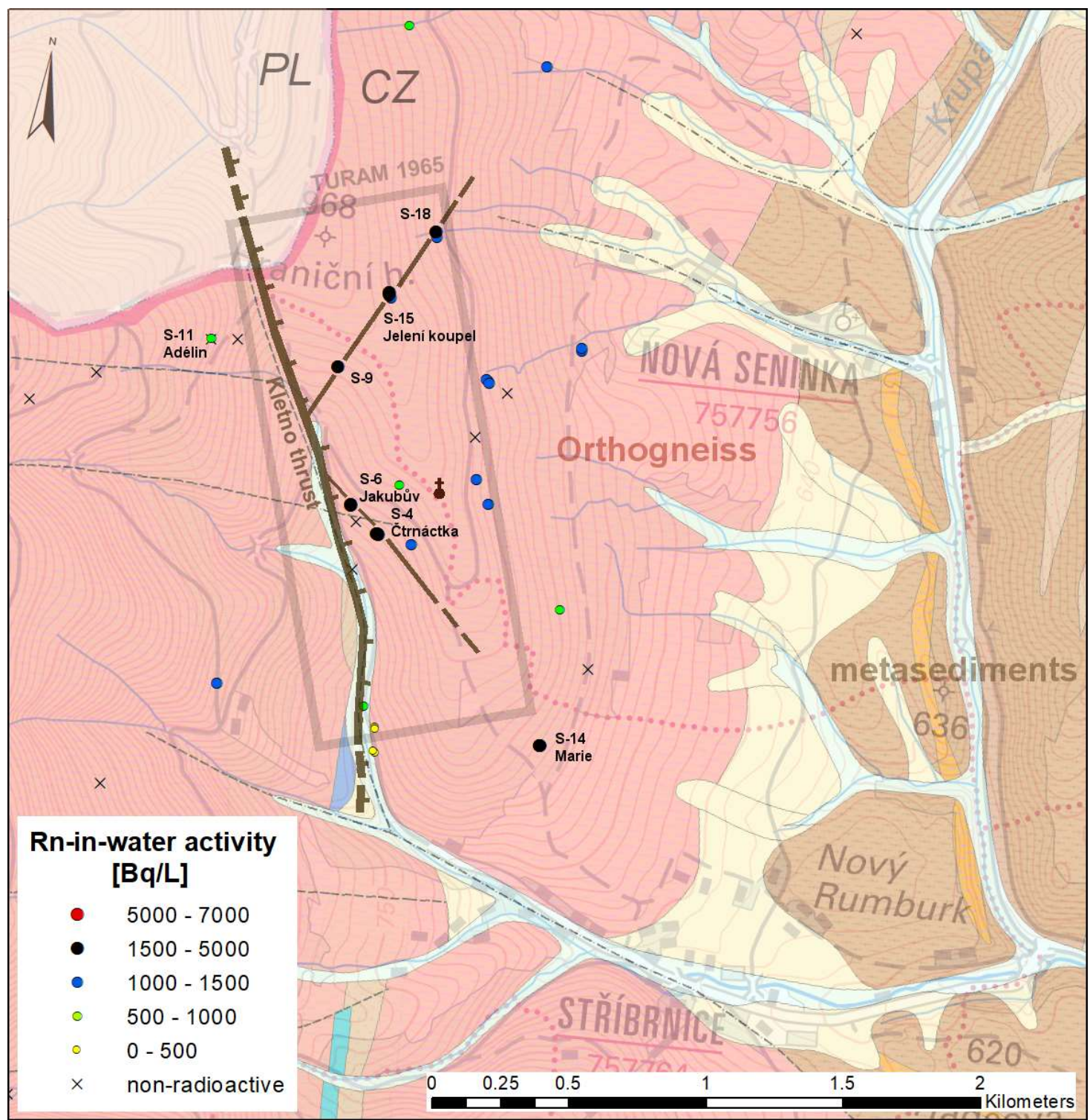

Figure 6. The Střibrnice cluster (Claim \#1) has an interpretation of the fault system according to the TURAM method. The position all of radioactive sources are controlled by faults in the hanging wall of the Kletno thrust (GIS composite). 


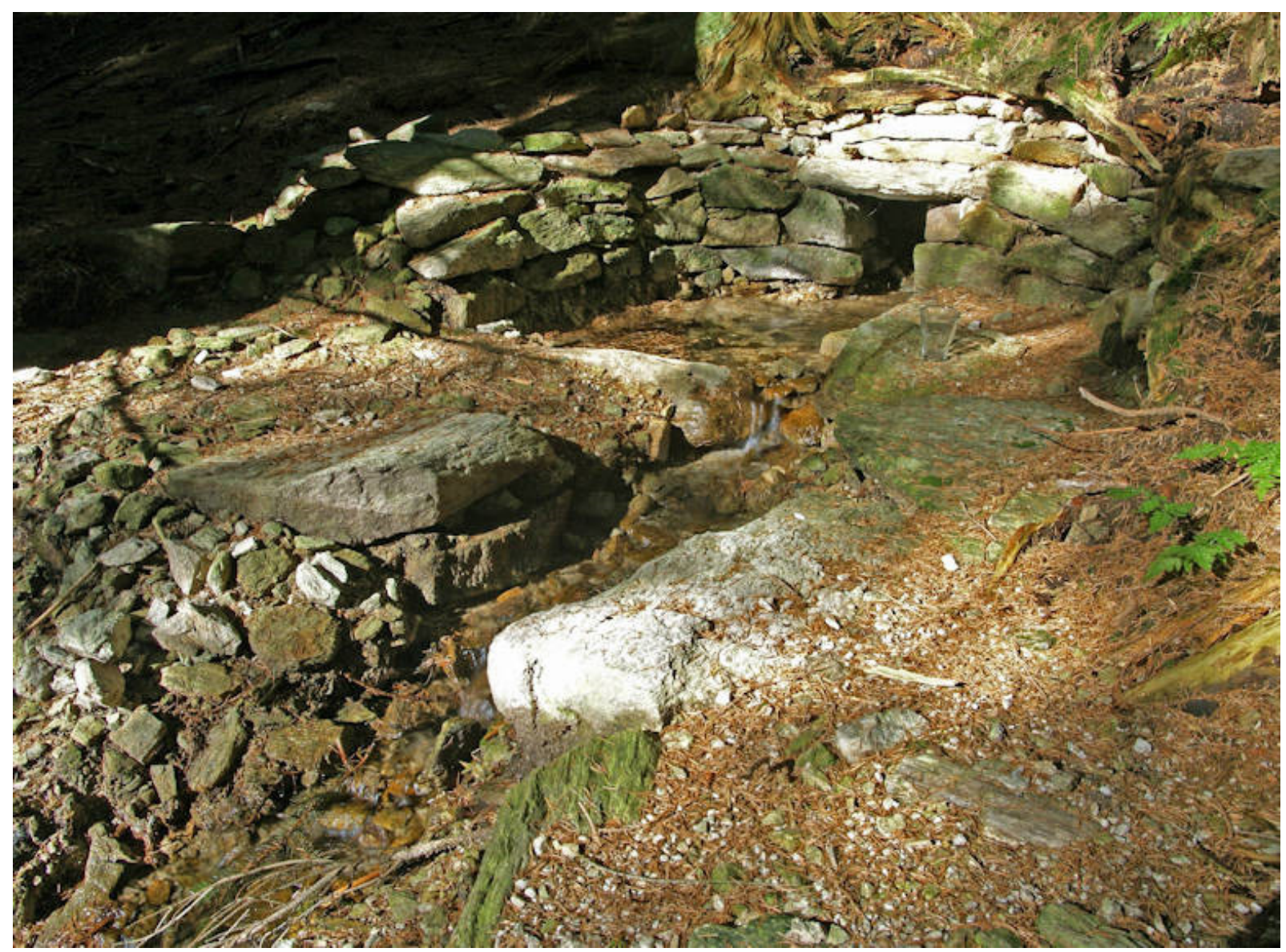

Figure 7. Jakubův spring in Střibrnice. Photo by Jiří Kamp, June 2006, with permission.

\subsection{Claim \#2-East Krkonoše}

Source rocks in Claim \#2 are both Krkonoše and Kowary orthogneisses as well as a small body of Krkonoše granite. The Krkonoše granite is highly differentiated rock of Variscan Krkonoše-Jizera pluton that consisted of fine-grained aplitic "granophyre" [23], with high $U$ and Th contents (28 ppm U and 31 ppm Th, laboratory gamma spectrometry).

There was only a short reconnaissance carried out since the spring Josefka ("Josephine") PL1 (2.7 kBq/L, 24 L/min) (Figure 8) was found originally by Vladimír Žáček (personal communication), during geological mapping by the Czech Geological Survey and field gamma spectrometry in the year 2012. It was revisited in the study. It had the highest placed radioactive spring in the whole Lugicum, and it flowed from a height of $1129 \mathrm{~m}$ a.s.l. This high-mountain area has not been systematically explored yet and remains promising.

The main source rocks in Claim \#2 are orthogneisses that form a mega-fold in the Krkonoše crystalline (Figure 8). Two sources in Velká Úpa, reported as radioactive in the literature, were discredited. In the Hofer spring (2.9 kBq/L, an unpublished 1936 report [39]), the level of radioactivity was found to be a maximum $879 \mathrm{~Bq} / \mathrm{L}$ and the Biskupský ("Episcopal") spring (1.8 kBq/L, by Wagner 1942 [60]) reported only 615 Bq/L. The explanation may lie in the rivalry and the effort to conceal the results between Czech and German researchers in a tense atmosphere before the World War II.

An important locality was found in the orthogneiss body bend at the north of Janské Lázně spa in a deep valley of the Černá hora creek [61]. The most important of the found clusters was the Bukový JL-6 (“Beech”) spring (up to 4.9 kBq/L, 2.9 L/min (Figure 8, Table 2, Appendix A). 
The Claim \#2 could not be systematically explored as the students fled the topic. The smaller border area of Kowary-Horní Malá Úpa was studied very intensively [62]. While the Kowary area was negatively affected by uranium mining and the hydrogeological situation changed. The best sources were found in Horní Malá Upa. Really unique was the spring Haida HMÚ-12 (up to $3.1 \mathrm{kBq} / \mathrm{L}, 74 \mathrm{~L} / \mathrm{min}$ ), a private source in a mountain pension.

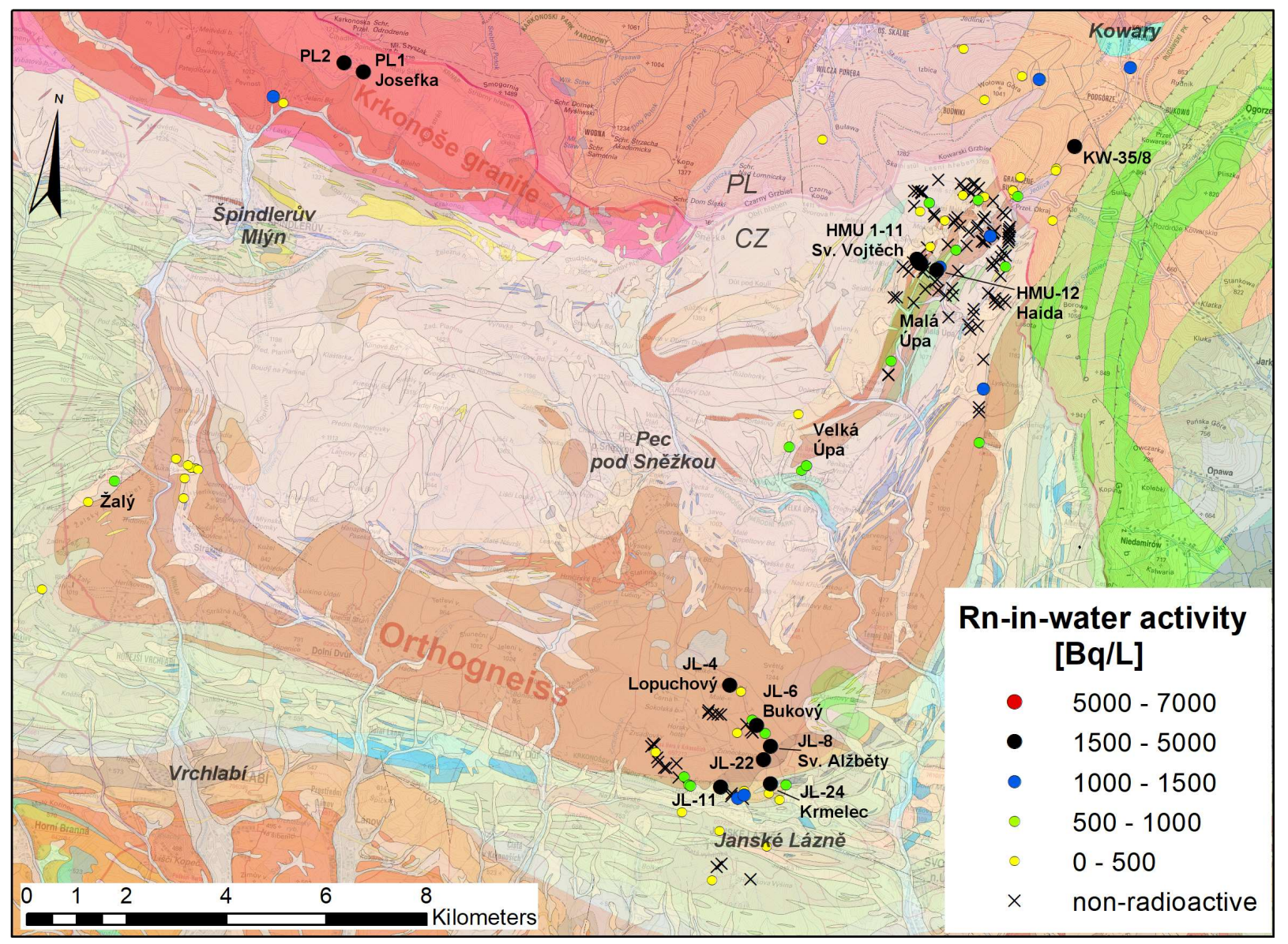

Figure 8. Radon-in-water activities in East Krkonoše, Claim \#2 (GIS composite).

At the same time, an investigation was carried out on the Polish side of the border, inside old iron and uranium mines in the Kowary town area. One water outflow KW-35/8 from the roof of adit no. 19a of the "Podgórze" mine was discovered with a ${ }^{222}$ Rn activity concentration of $2.7 \mathrm{kBq} / \mathrm{L}$. The source of water were cracks cut in orthogneiss [63].

The most explored spring was Sv. Vojtěch ("St. Adalbert") due to the fact of its fair geological exposure and the use of geophysical methods. Here, exists a cluster of eleven springs in line (HMÚ 1-11) with activities up to $4.2 \mathrm{kBq} / \mathrm{L}$ bound to the edge of the orthogneiss band (Table 2, Appendix A). The site was discovered during the uranium survey and was briefly examined in the period 1951-1952 [64]. It was later abandoned as non-promising. The information was kept secret and became forgotten; the spring was rediscovered in 2008. The spring outflows are localized at a transverse fault filled with impermeable illite-chlorite-talc clay formed as a reaction product on the orthogneiss and dolomite body contact (Figure 9). 
The clay forms a hydrogeological barrier with a thickness of at least $20 \mathrm{~m}$. In the adjacent tectonized mafic orthogneisses, uranium mineralization occurred. It is represented only by amorphous hydrated oxides of Ti-Fe-U, the so-called "uranium leucoxene". This mineral is likely the source of water activation. The site was explored further. The Sv. Vojtěch springs are well known and popular with the public.
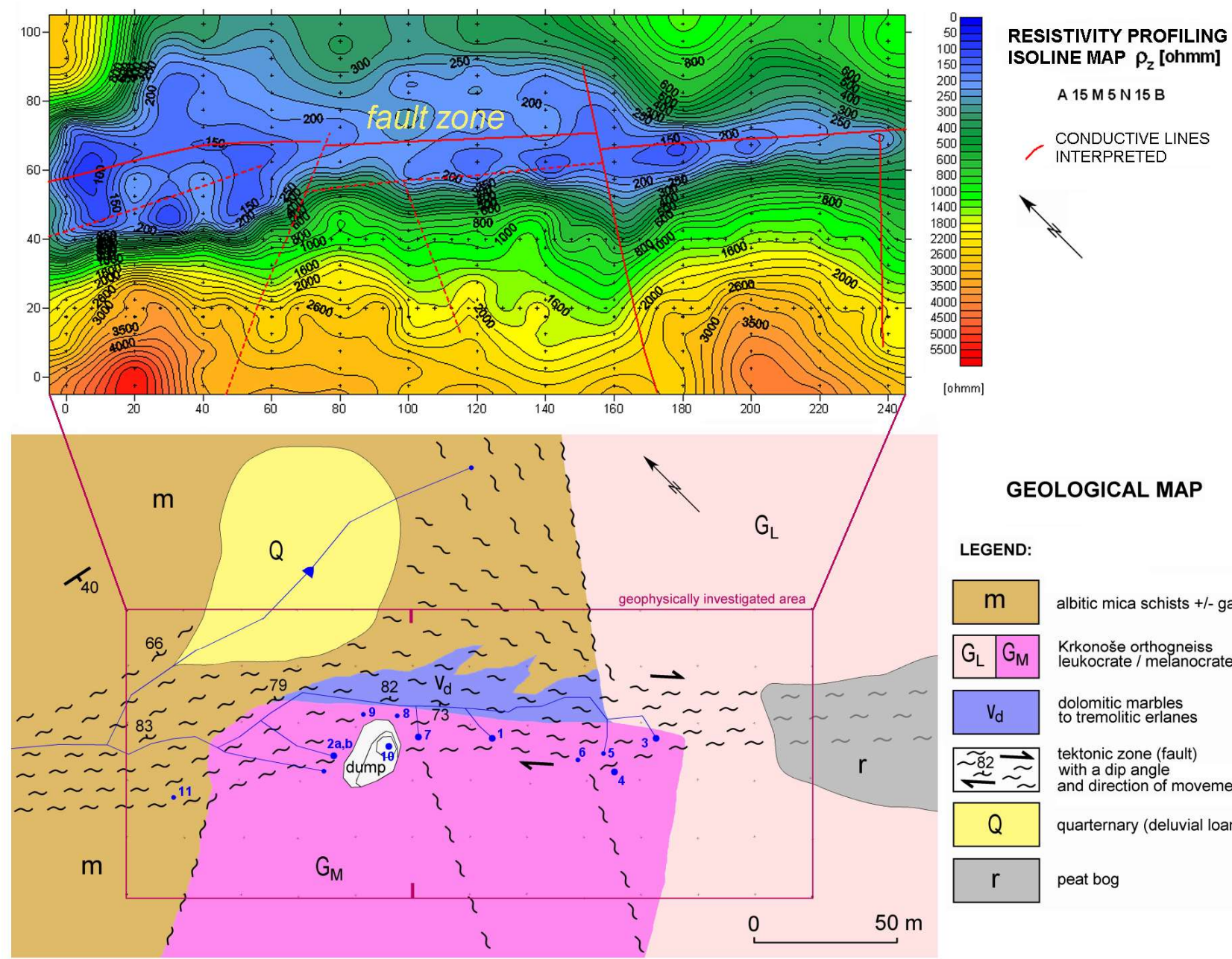

GEOLOGICAL MAP

LEGEND:

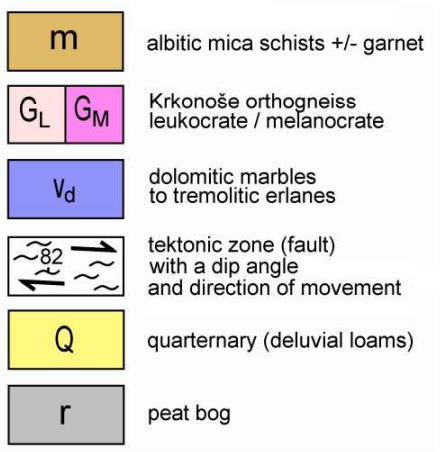

Figure 9. A detailed hydrogeological situation of Sv. Vojtěch spring in Horní Malá Úpa, Krkonoše. Outflows of 11 springs HMÚ-1 to 11 were localized in the line of the highest resistivity gradient, i.e., on the edge of the clay fill of the fault zone. Modified from [62].

\subsection{Claim \#3-Lázně Libverda-Śzieradów-Zdrój}

According to the general map (Figure 4), the Jizera orthogneiss occupies a large area, but in fact, they are mostly covered by Quaternary glacial (Pleistocene) sediments in the northern foothills of the Jizera Mountains [65] (Figure 10). There flows much acidulous water, mostly in the metasedimentary belt, which has long been used in the well-known spas (Lázně Libverda spa, Świeradów-Zdrój spa). However, they usually have low activities. Only in the Świeradów-Zdrój spa have the long-known radioactive waters been used since 1934. Water with activities ranging from 247 to $1517 \mathrm{~Bq} / \mathrm{L}$ have been captured for the purpose of radon baths [66]. 


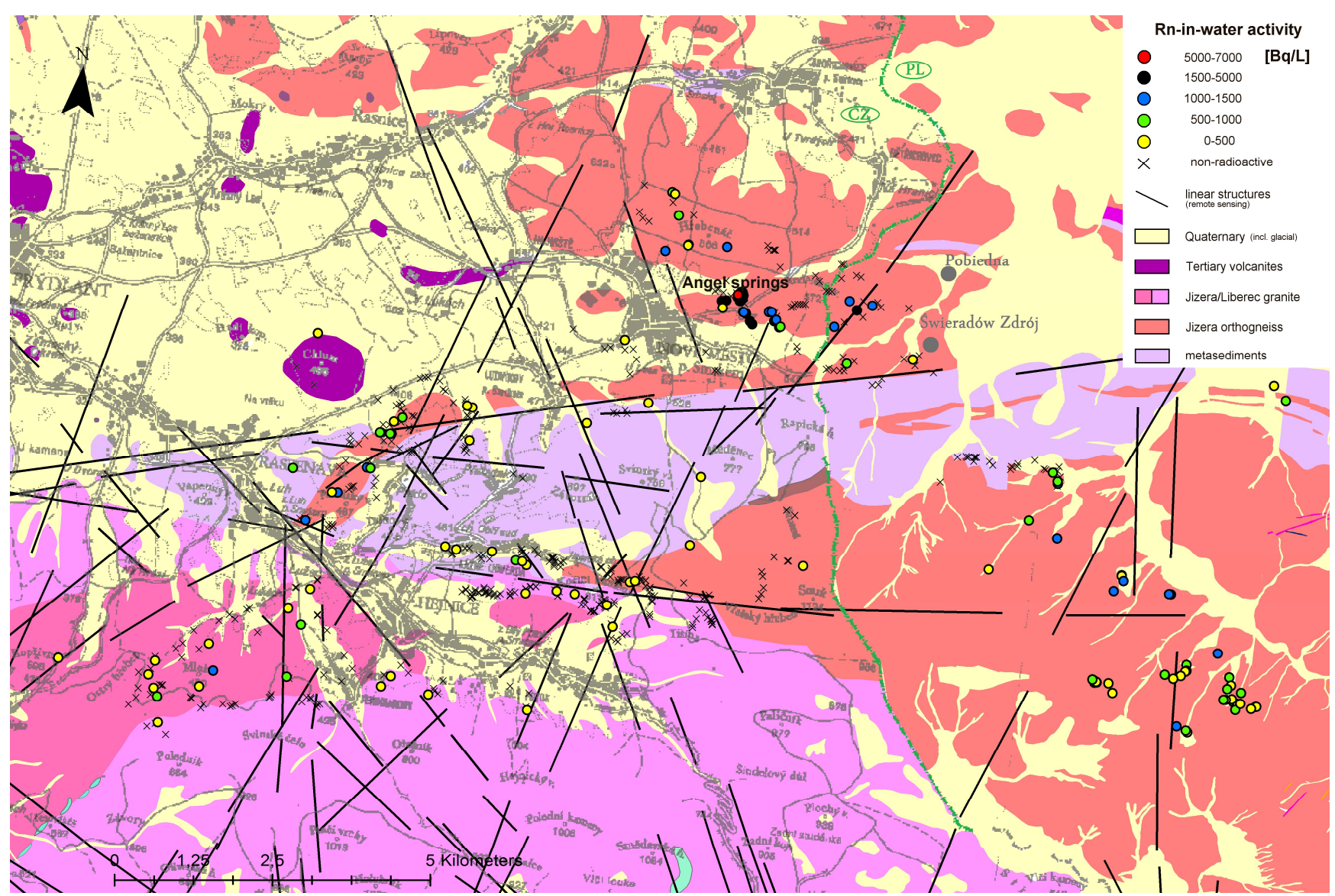

Figure 10. Radon-in-water activities in the Lázně Libverda-Świeradów-Zdrój area, Claim \#3 (GIS composite)s.

During the preparatory phase, east of Lázně Libverda was recognized as the most hopeful area, the zone of contact of the orthogneiss with the Liberec granite, but it was completely barren. However, in 2010, a very significant cluster was found in the northern part of the claim [67]. At this place, which was named Angel Springs in this study, were found 17 water manifestations (i.e., springs, wetlands, and side inflows into streams) with increased radioactivity (Figure 11). The spring area is partly covered by glacial clayaceous sediments with a thickness of up to $4 \mathrm{~m}$. Therefore, it was explored by a complex of geophysical methods (very low frequency, 2D multielectrode resistivity and seismic profiles, magnetometry, and gamma spectrometry) that revealed the underlying geological situation. The main sources are the Michael spring L3/6, the most active source of the entire Lugian area (up to $6.2 \mathrm{kBq} / \mathrm{L}, 0.37 \mathrm{~L} / \mathrm{min}$ ), and the Rafael spring $\mathrm{L} 3 / 9$ (up to $3.2 \mathrm{kBq} / \mathrm{L}, 24 \mathrm{~L} / \mathrm{min}$ ) (Table 2, Appendix A); together they accounted for $52 \%$ of the total flowrate of the Angel springs. A great attraction and rarity is the Samuel spring L3/14, as it forms natural ponds with radioactive peloids (peat suspension with an activity of approximately $2.1 \mathrm{kBq} / \mathrm{L}$ ) suitable for bathing. The location of the Angel springs is now very popular and frequently visited as a natural healing place and forest balneopark [68]. Spa doctors in Lázně Libverda also recommend them for supplementary treatment. 


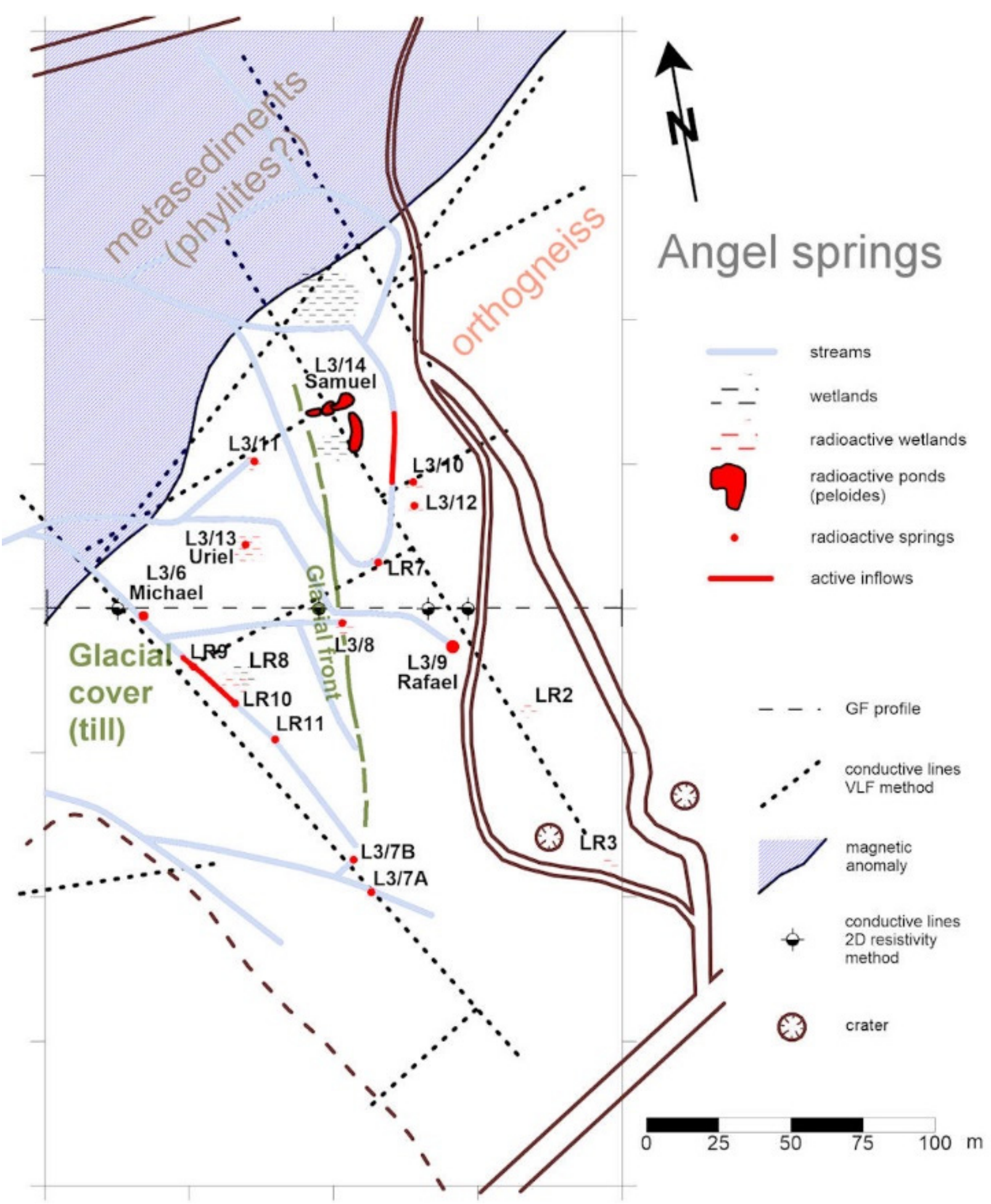

Figure 11. Locality of the Angel springs near Nové Město p. Smrkem. Situation of the radioactive sources with interpretation of geophysical survey.

\subsection{Claim \#4-Chrastava-Bogatynia}

As in Claim \#3, the northern foothill in Claim \#4 is also covered with the glacial sediments. Under the hill, there lies the Tertiary Zittau basin. In the exposed area, the Jizera orthogneiss is in contact with the Variscan (i.e., Liberec and Jizera) granites. The claim area also includes a small block of the Variscan Tanvald granite near Bedřichovka, displaced 
from its main body in the northwest direction. There was also found a significant cluster of radioactive springs with activities up to $2.8 \mathrm{kBq} / \mathrm{L}$ [69] (Figure 12).

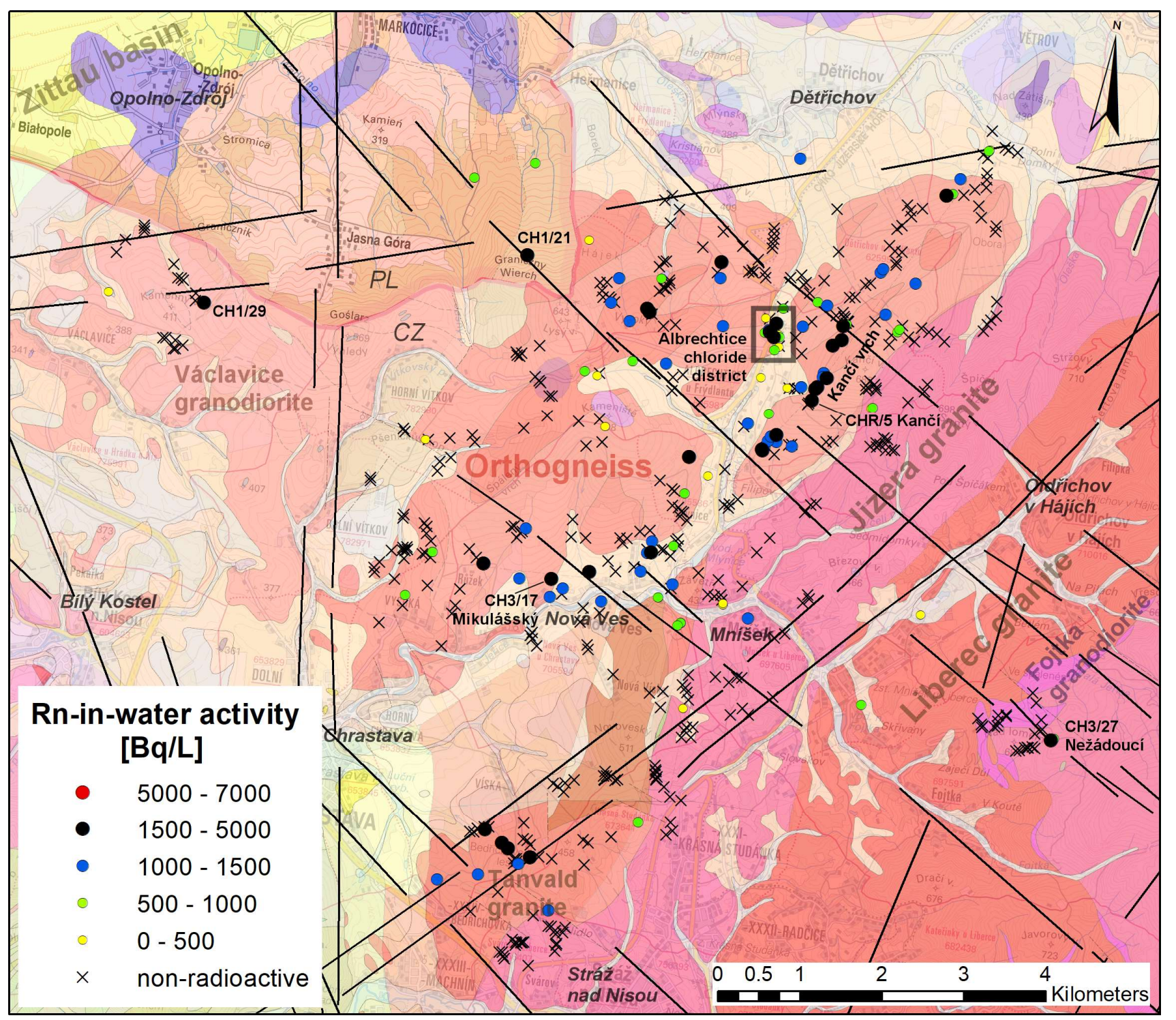

Figure 12. Radon-in-water activities in the Chrastava-Bogatynia area, Claim \#4 (GIS composite).

However, the main source rock here is the Jizera orthogneiss. An important line of springs lies on the hill Kanči vrch, based on its contact with the Variscan (Liberec) granite. The Kančí ("Boar") spring CHR/5 (up to $2.1 \mathrm{kBq} / \mathrm{L}$ and $3 \mathrm{~L} / \mathrm{min}$ ) was also important (Figure 12). It is also necessary to mention the strong Mikulášský ("St. Nicholas") spring CH3/17 in Nová Ves near Chrastava (Table 2, Appendix A).

The most interesting is the discovery of a cluster of radon-chloride waters in Albrechtice near Frýdlant, which was examined in detail [70]. There are multiple sources in this cluster (Figure 13). The main sources are the spring Matka ("Mother") CHR/11 (approximately $2.3 \mathrm{kBq} / \mathrm{L}, 22 \mathrm{~L} / \mathrm{min}, \mathrm{Na}-\mathrm{Cl}$ type with a TDS of $0.67 \mathrm{~g} / \mathrm{L}$ ) and the most mineralized Soumar ("Sumpter") spring CH2/11 (Na-Ca-Cl type with TDS of 1.1-1.5 g/L) (Table 2, Appendix A). The site is anthropogenically affected in the immediate vicinity of the I/13 Liberec-Frýdlant main road. But the quantitative parameters support its natural origin, i.e., approximately 10 tons of salt come out just from the two main springs (Soumar and Matka) annually. It is four to five times more than what is used for winter maintenance of that road (ing. Vrba, Roads and Motorways Directorate in Liberec, personal communication). 


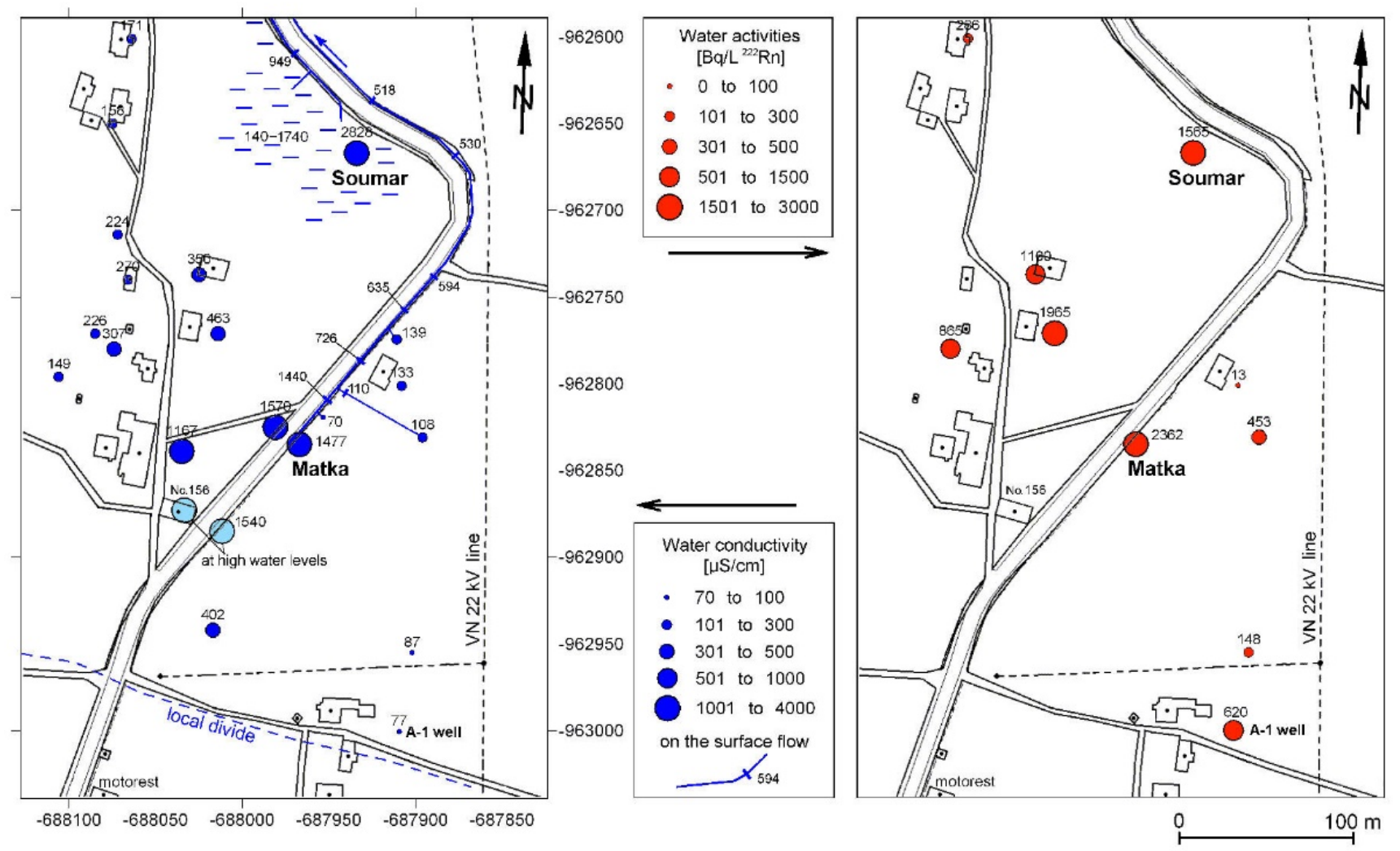

Figure 13. The Albrechtice chloride district. Modified from [70].

At this moment, it is opined that the chloride mineralization has a natural origin. This could be related to the Eger rift fault system [71] or to the chloride brines drilled in Zittau basin bedrock [72], also affecting the head of the glacial front [65]. Nevertheless, more explanatory options exist here. A strong argument for the natural origin of chloride mineralization is the activity of radium in the Soumar spring. Water has an elevated content of $1.7 \mathrm{~Bq} / \mathrm{L}^{226} \mathrm{Ra}$. It is at least ten times higher than the radium level in the surrounding non-mineralized waters. For chloride brines, a high content of radium is typical (e.g., [73]) while road salts show low (only background) activities.

The origin of these sources is unclear as in the case of many other mineral water sources. The fact that the saltiest waters were also the most radioactive is particularly interesting. Sources of salty, non-radioactive waters have not been found there. The hypothesis of the anthropogenic origin is still being considered, with the critical role of land use, especially using deicing salt, influencing (ground) water chemistry [74,75]. In any case, a mixed radon-chloride type of mineral water (by definition) arises here, which is new to the whole area of the Eger rift zone.

\subsection{Claim \#5-Tanvald Granite}

The entire main body of the Variscan Tanvald granite was explored at the end of the campaign under the influence of positive findings on Claim \#4 combined with the known historical data [76]. This rock had a different geochemistry than most of the KrkonošeJizera pluton body. The Tanvald granite is an alkaline S-type, while in the other parts of the pluton, the granites are a calc-alkaline I-type [77].

The eastern part of the elongated body of Tanvald granite proved to be completely barren, including an auspicious triple point with the Liberec granite and metasediments, where a uranium occurrence was explored between 1955 and 1957 in the neighboring area near Príchovice [27]. Radioactive springs were found only in the central and western parts of the body (Figure 14). 


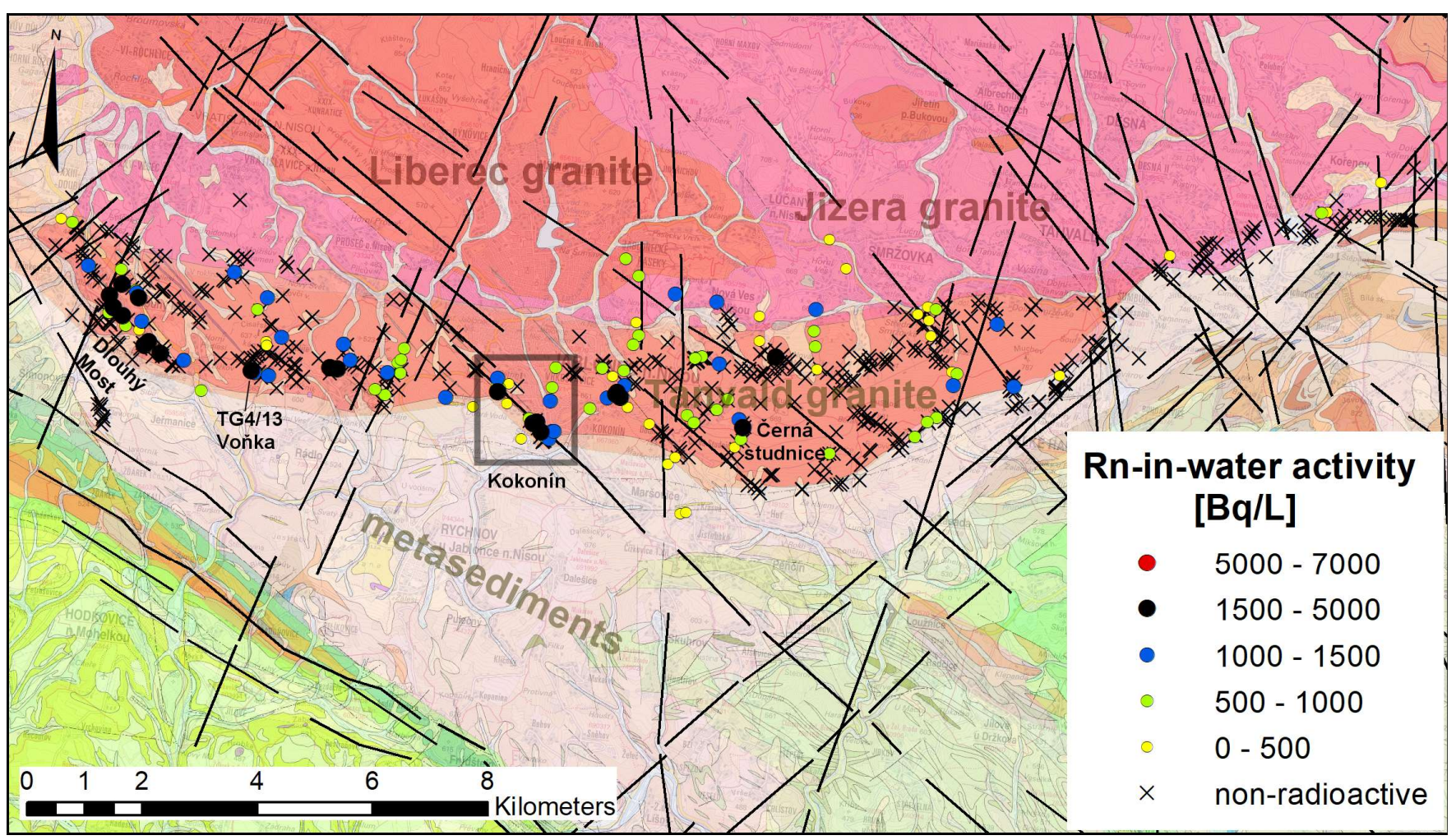

Figure 14. Radon-in-water activities in the area of Tanvald granite, Claim \#5 (GIS composite).

Historically, radioactive waters are known the most in the village of Dlouhý Most [60]. Although, due to the high radioactivity of local waters, the village was connected to a remote water supply in 1993; still, there are seven rarely used sources with activity above $1500 \mathrm{~Bq} / \mathrm{L}$, with the highest activity of $2.4 \mathrm{kBq} / \mathrm{L}$ in a private, however, publicly accessible Oudrnický family well (TGR/11). High water activities have also been confirmed at Černá Studnice hill, in the catches (shallow wells) for the public, now unused water supply for the Jablonec town [60]. The highest activity was found in the "Object No. 16" (TG4/17, $2.1 \mathrm{kBq} / \mathrm{L})$. The most active source of the whole Claim \#5 is the private Voňka spring TG4/13 (3.2 kBq/L, 1.2 L/min), located in the northwest of Rádlo village.

An important cluster was found in the central part of the Tanvald granite body near the Kokonín village (now as a part of the Jablonec nad Nisou town). The springs are controlled by the Kokonín fault, the most important tectonic line of the whole body of the Tanvald granite, which dislocates its contact with the surrounding metasediments for a distance of $1 \mathrm{~km}$ (Figure 15).

Uranium mineralization was also found in the surroundings of the Kokonín fault line [30]. There exists the most important (according to its radiation flow) spring of the whole body, the Schindler spring TGR/33 (up to $2.6 \mathrm{kBq} / \mathrm{L}$ and $29 \mathrm{~L} / \mathrm{min}$, Table 2, Figure 16). It is mineralized by chlorides as well as other springs in the cluster ( $\mathrm{Na}-\mathrm{Ca}-\mathrm{Cl}$ molar type, Appendix A). The spring is in the city park, and until the 1980s, it served as a tap water source for Kokonín village. There was no information about its high radioactivity until it was found in 2014. A project to utilize it as a medicinal source is under preparation in parallel with the revitalization of the park. 


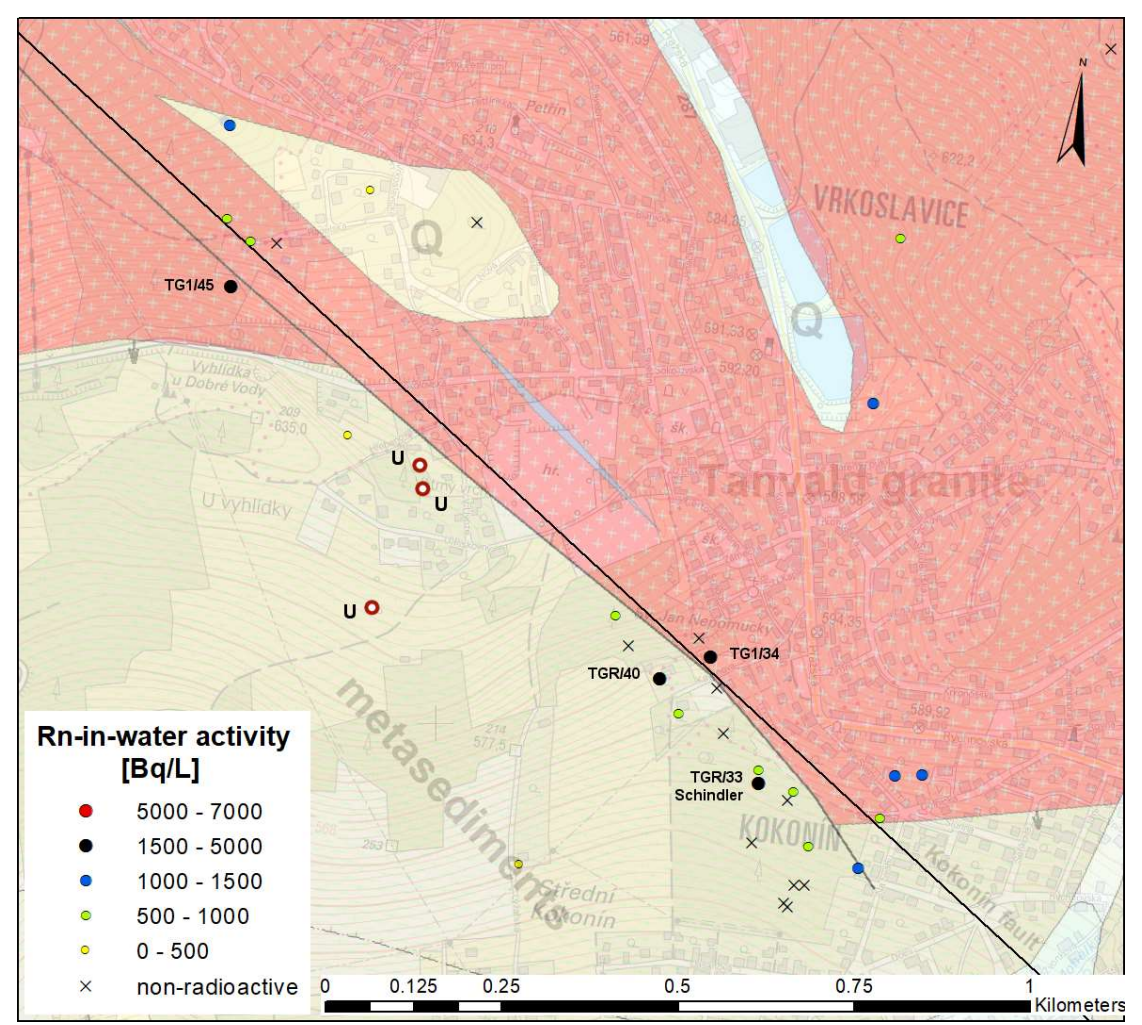

Figure 15. The Kokonín cluster with a position of radioactive water sources and outcrops of uranium mineralization. Modified from [30].

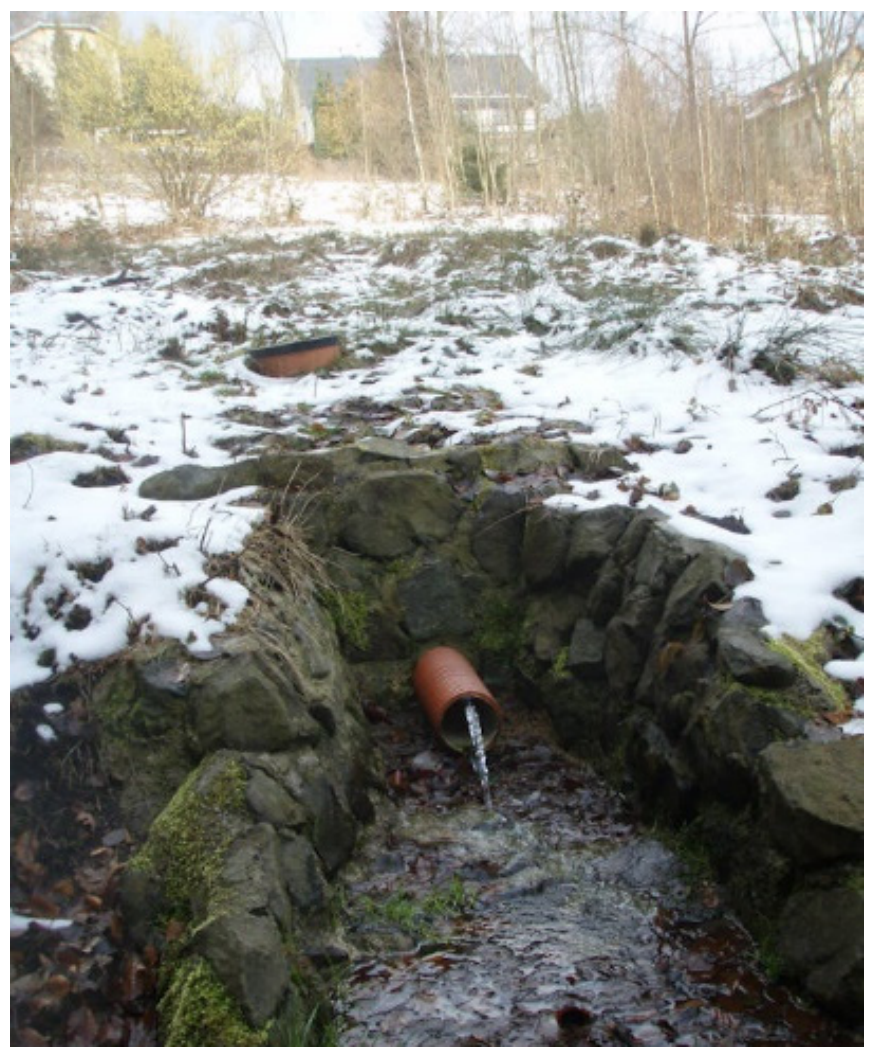

Figure 16. The Schindler spring in Kokonín park, March 2016. The original waterworks building was demolished, and the water was drained in 2013. Photo by Viktor Goliáš. 


\section{Discussion}

\subsection{GIS Usability}

Great hopes are always put on the stage of claim preparation before the start of field exploration. The success of the predictions according to GIS layers has always been evaluated at the end (Table 3). The only usable GIS layer with a positive correlation to the findings in all claims was a geological map. The data layer for the uranium survey anomalies [43] was mostly in line with the findings. However, it was found that looking for single anomalies is not worth the effort, as their location was poorly accurate (in the relatively large scale of 1:50,000) and the fieldwork could become unnecessarily delayed. Often, these anomalies could not be found at all. Moreover, they were not even bound to water. Rather, it made better sense to explore clusters of radiometric anomalies as perspective areas and to measure only water manifestations.

Table 3. Applicability of layers to search for sources of radioactive mineral springs in Claims \#1-5. The code indicates the subjective contribution of the data layer for the localization of positive findings: + positive, (+) weakly positive, - negative, 0 neutral, n.u. not used, n.a. not available.

\begin{tabular}{|c|c|c|c|c|c|c|}
\hline GIS Layer & Server & Claim \#1 & Claim \#2 & Claim \#3 & Claim \#4 & Claim \#5 \\
\hline Geological map 1:50,000 & geology.cz & + & + & + & + & + \\
\hline Map of radon risk $1: 50,000$ & geology.cz & - & n.u. & n.u. & n.u. & n.u. \\
\hline Topographic map 1:50,000 & inspire.cz & 0 & 0 & 0 & 0 & 0 \\
\hline Anomalies of uranium survey & local & + & + & $(+)$ & + & $(+)$ \\
\hline Linear structures (remote sensing) & local & n.a. & n.a. & 0 & $(+)$ & $(+)$ \\
\hline Uranium map (aeroradiometry) & local & n.a. & n.a. & + & $(+)$ & $(+)$ \\
\hline
\end{tabular}

The maps of the radon risk seemed initially promising. At the Claim \#1, however, it was found that they are constructed mostly "from the table", and areas with orthogneisses (such as metamorphic rock) had an intermediate radon-risk value (e.g., [78]). In contrast, all the Variscan granites were classified by high Rn-risk, but their fertility for radioactive waters was low in the area explored. The study evaluated the applicability of radon index maps as negative, and those were no longer used on subsequent claims. It is also believed that the modern trend of regional radon maps [79] had a grid that was too large for the purposes of this study. It was unsuitable for the solution of local problems, as it was only informative, and it was also unusable for the purposes of radioactive water exploration.

The GIS data layer of the linear structures [47] was used only in Claims \#3-5. It was slightly useful in the cases where radioactive sources were bound to tectonic lines of regional importance. In the same claims, the applied layer of uranium concentrations from airborne gamma spectrometry [46] was positive only if the radioactive sources formed a tight cluster that could be detected from a greater height. However, that has only been achieved in the case of Angel springs, and this fact was secured retroactively after their discovery. Otherwise, rock outcrops mainly caused increased uranium concentrations.

It turned out that the preparation of the claims in the GIS environment was not omnipotent as was assumed in [80]. Field exploration played a more important role. In some cases (mainly in Claim \#3), it was observed that some perspective areas after GIS (with many faults, a favorable contact of orthogneiss with Variscan granite and many springs according to topographic data) proved completely barren. The radioactive waters were discovered in the wings of the claim, in the places that originally were considered insignificant. Simply, it can be said that a radioactive spring was found when one comes to it, as it cannot be found solely from the maps and GIS outputs. Based on the experience, it is best to explore the claim entirely. 
No dependence on surface morphology was observed. The only but very important finding was that radioactive springs usually do not occur separately but in clusters. It is, therefore, in the case of individual findings, a good idea to explore the surrounding area in detail.

\subsection{Radon Activity Concentration and Gamma Dose Rate Relationship}

Gamma dose rate was used as a proxy to determine radon potential [81,82]. Importantly, the gamma dose rate was higher in virtually all cases of the radioactive groundwaters, and it is important for the indication and sampling of water for radon determination. On the contrary, the manifestations of normal (non-radioactive) waters cause minimums to be measured in the field because the water acts as an effective shield and the gamma radiation is attenuated. The gamma dose rate in water and radon activity concentration relationship is complicated; both values show a weak positive correlation (Figure 3a). It depends on the specific situation of every single spring. The highest gamma dose rate is often found outside the primary inflow where water flows slowly, despite that primary (flowing) water has always been sampled, if there was any. A large number of sources were encountered that were rich in radon even at relatively stagnant water. However, the rapidly draining water(s) flowing in gravel indicated a low gamma dose rate (cf Figure $3 b$ ). It is necessary to sample it even at the slightest increase in the gamma dose rate. In contrast, live aquatic plants, such as mosses and filamentous algae, have always shown the highest gamma activity (Figure $3 b$ ). This is because the slow flow causes radon delay and development of radioactive equilibrium with its short-lived gamma active products during plant metabolism $[83,84]$.

It can be concluded that the gamma dose rate-in-water is not a function of just radon activity concentration but also of radioactive equilibrium level, which is controlled by water velocity, flow rate, and level of biological activity (1):

$$
D_{w}=f(A v, v, F, B)
$$

\subsection{Effectivity of the Gamma Indication Method}

To prove the effectiveness of the method, the whole data set of radon activity concentrations was divided into two groups: The first group contained sources where only radon activity was known, and gamma dose rate had not been measured (a small part of Claims \#2 and \#3 on the Polish side) or could not be measured for some reason (e.g., pumped well waters, tap waters). This set, therefore, represented the classical systematic sampling of water (Figure 17a). The second set consisted of radon activity concentrations for which gamma activity was measured. This represented the net use of the gamma indicative method in the same area studied (Figure 17b). It is evident from the histograms that both data sets had lognormal-type distributions, and the gamma indication method strongly suppressed the detection capability in the lowest class interval $0-500 \mathrm{~Bq} / \mathrm{L}^{222} \mathrm{Rn}$, which is methodically ignored as a "negative" result. On the contrary, the probability of successful detection in classes above $1500 \mathrm{~Bq} / \mathrm{L}^{222} \mathrm{Rn}$ was much higher compared to the systematic sampling results (relative frequency of $22 \%$ vs. $5.7 \%$, respectively).

It is certainly possible that there was (unwanted) omission of an active water source. On the other hand, none of the sources exhibiting $>1500 \mathrm{~Bq} / \mathrm{L}^{222} \mathrm{Rn}$ had an increase in a gamma dose rate of less than $317 \mathrm{nGy} / \mathrm{h}$ over the natural background. Which is certainly a value that cannot be ignored. 


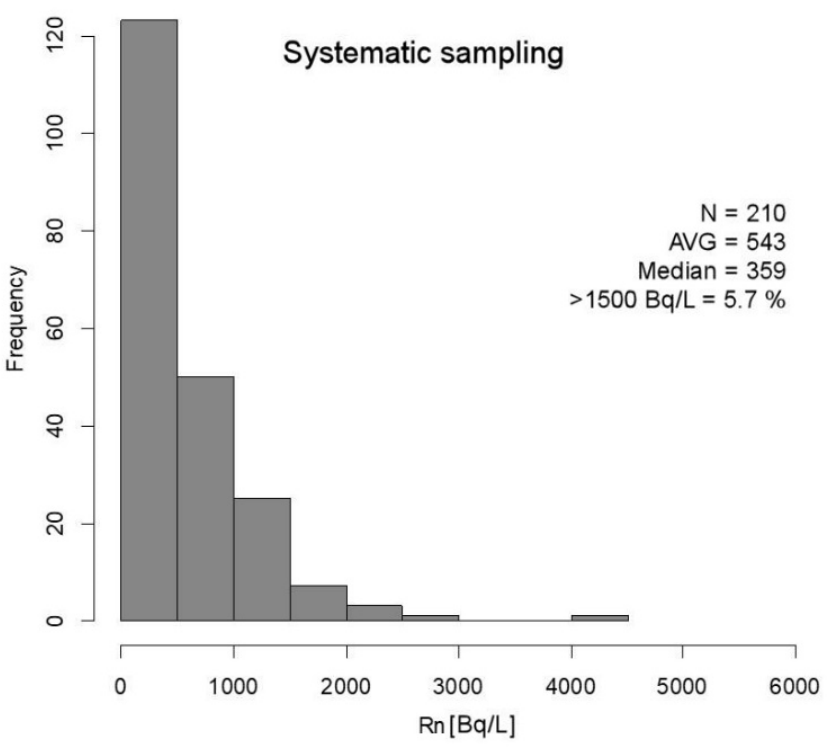

(a)

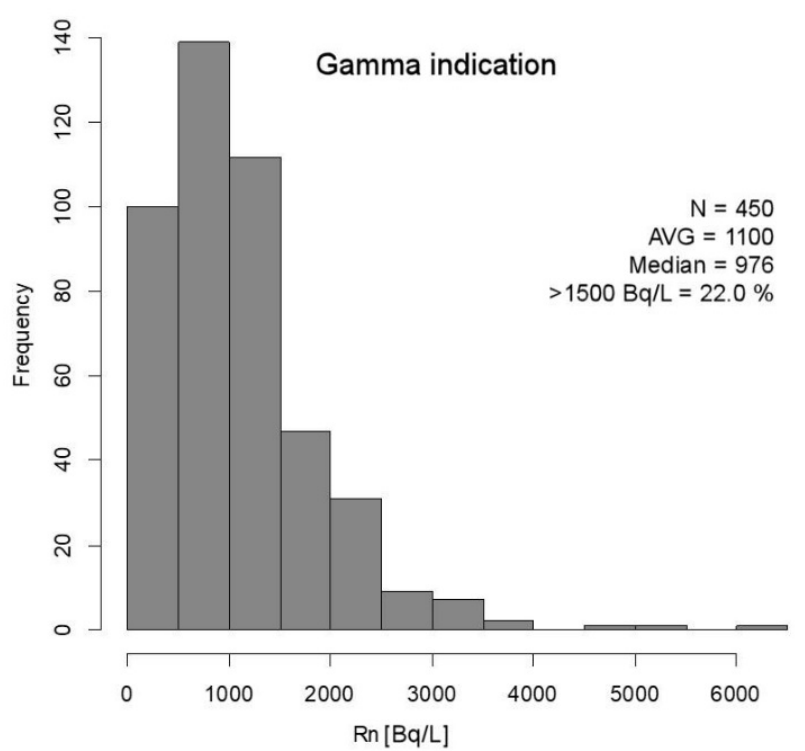

(b)

Figure 17. Histograms of water activity distribution of the parts of the data set where the activity was not or could not be measured, representing classical systematic sampling (a) and where gamma activity was measured representing the gamma indication method (b).

\subsection{Activation Process Remarks}

Most waters found had low temperatures and high Eh. According to [85], such waters demonstrated shallow circulations in equilibrium with the oxidation zone. Such a link mechanism is, however, highly simplified, so it cannot be applied universally, and there are certainly other mechanisms of genesis (activation). For example, the KSS- 1 borehole (Claim \#1) was completely beyond the reach of hypergenesis as evidenced by its relatively low Eh.

In principle, three types of aquifers can be found in these crystalline bedrocks: Quaternary (superficial deposits), surface-loosening zones (shallow fractures), and true faults (deeper fracture zones) [86]. Wherever data were available, radioactive sources were always bound to significant fault systems demonstrated by geophysics (Střibrnice, Angel springs, Schindler spring, St. Vojtěch springs). Significant springs are mainly bound to the aquifer of the third type. Only permeable faults that allow deeper water circulation may also enable communication with other aquifers [87] as is suggested by the occurrence of radon-chloride waters in the Claims \#4 and \#5.

Discovered for-medicinal-use high-enough radon activity concentrations were rare. The rock itself cannot activate water to such levels. In that case, springs would be everywhere. The term "source rock" (Table 1) was used in the sense that such a rock, in different geological periods, is able to easily release radionuclides, which can precipitate secondarily and can create a richer accumulation of $\mathrm{U}(\mathrm{Ra})$ or just ${ }^{226} \mathrm{Ra}$ (than that of the primary source rock) which, in turn, can activate water to these high levels in the aquifer. The mechanism of accumulation of radium onto $\mathrm{Mn}$ and Fe oxides in aquifers and subsequent activation of water by radon is well described in $[88,89]$. On the other hand, $\mathrm{U}(\mathrm{Ra})$ mineralization is proven in the case of Sv. Vojtěch springs and probably at Schindler spring, while Soumar springs is to be considered as a typically Ra-type. In the four cases, the geochemical as well as the hydrogeological barrier was documented at the tectonized contact of two different rocks: Orthogneiss vs. calcareous siltstone "opuka" (Dolní Hedeč cluster, Claim \#1), orthogneiss vs. dolomite (St. Vojtěch springs, Claim \#2), orthogneiss vs. phyllites(?) (Angel springs, Claim \#3), and finally, Tanvald granite vs. mica schists (Kokonín cluster, Claim \#5). It can be said that these are springs of the barrier-type. For other springs, it is difficult to conclude because the underground source was not visible and the zones of their activation remains a mystery. In addition, the influence is very questionable (possibly the formation 
of springs?) by the glacial front in the case of Angel and Soumar springs in Claims \#3 and \#4, which are at exactly the same altitude (511-518 $\mathrm{m}$ a.s.1.) as well as the Elsterian 2, a glacial ice sheet limit in this area was determined at the altitude $470-490 \mathrm{~m}$ a.s.1. [65].

A suitable activation situation can certainly arise through various genetic mechanisms. From a geological point of view, each radioactive spring is rare and unique.

\section{Conclusions}

In the countries where radioactive sources have traditionally been considered miraculous and healing, even the obscurantism of the irrational fear of radioactivity failed to change or eradicate it.

Many important new sources of healing radon waters with high balneological potential have been discovered in the area explored. Some of the newly found sources have become a regular tourist attraction and highly praised places of relief, comfort, and succor such as the Angel springs forest Balneopark built by the local community.

It has been demonstrated that despite the various levels of the radioactive equilibrium of the radon and its gamma active progeny $\left({ }^{214} \mathrm{~Pb}\right.$ and $\left.{ }^{214} \mathrm{Bi}\right)$, the correlation of the radon activity concentration and gamma dose rate in water was statistically significant under real natural conditions. Thus, the gamma indicative method is significantly more advantageous for the exploration of radon-rich waters in crystalline terrain based on the empirical field findings than the classic systematic sampling because it saves energy, time, and money. Thus, the operative and effective method described herein and successfully tested in the field can be recommended for the exploration of radioactive (radon) mineral water sources in other perspective crystalline fields around the world.

Supplementary Materials: The following supporting information can be downloaded at: https: / / www.mdpi.com/article/10.3390/w14020200/s1, Table S1: All data on Rn activity concentrations, gamma dose rates, and position of sources in both coordinate systems (i.e., JTSK and WGS84) for the whole Lugian area measured.

Author Contributions: Conceptualization, methodology, supervision, writing-original draft preparation, and funding acquisition, V.G. and T.A.P. and R.P.; investigation, V.G., L.H., T.L., T.Č., P.K., T.A.P., J.D., L.S., A.K., L.F.-L., W.M. and R.N.; data statistical treatment, J.J. and R.P.; data validation, visualization, and writing-review and editing, L.H. and T.L. All authors have read and agreed to the published version of the manuscript.

Funding: For the financial support, we would like to thank the following projects: MSM0021620855, GA ČR 205/07/0522, MEB051016, MEB050812, GA UK 756213, and the CZ-PL Forum of the MFA ČR.

Data Availability Statement: Data is contained within the article and Supplementary Material.

Acknowledgments: We would like to thank, in particular, individuals from the DIAMO state enterprise (Jaromír Ondřík, Pavel Veselý, and Vladimír Stoje), Krkonoše National Park (KRNAP), Forests of the Czech Republic, Czech Geological Survey, Charles University, Faculty of Science (Václav Kachlík, Milan Matolín, Jan Vilhelm, Jan Valenta, Stanislav Smrček, Jiří Bruthans and other colleagues), Czech University of Life Sciences Prague (Václav Tejnecký), the nonprofit initiative of the National Register of Springs (www.estudanky.eu) (accessed on 11 November 2021), local communities representatives as well as numerous students and other fans of radioactive springs for their generous assistance in the field and their selfless help.

Conflicts of Interest: The authors declare no conflict of interest. The funders had no role in the design of the study; in the collection, analyses, or interpretation of data; in the writing of the manuscript, or in the decision to publish the results. 


\section{Appendix A}

Table A1. Chemical composition of the ten most important sources of radioactive mineral waters from the Lugian area.

\begin{tabular}{|c|c|c|c|c|c|c|c|c|c|c|c|}
\hline Name & & Čtrnáctka & Jakubův & - & $\begin{array}{c}\text { St. } \\
\text { Vojtěch }\end{array}$ & Bukový & Michael & Rafael & Soumar & Mikuláš & Schindler \\
\hline Code & & S-4 & S-6 & KSS-1 & HMÚ-1 & JL-6 & $\mathrm{L} 3 / 6$ & $\mathrm{~L} 3 / 9$ & $\mathrm{CH} 2 / 11$ & $\mathrm{CH} 3 / 17$ & TGR/33 \\
\hline $\begin{array}{l}\text { Claim } \\
\text { Number }\end{array}$ & & $\# 1$ & $\# 1$ & $\# 1$ & $\# 2$ & $\# 2$ & $\# 3$ & $\# 3$ & $\# 4$ & $\# 4$ & $\# 5$ \\
\hline Locality & & Stříbrnice & Stříbrnice & $\begin{array}{l}\text { Dolní } \\
\text { Hedeč }\end{array}$ & $\begin{array}{l}\text { H. M. } \\
\text { Uppa }\end{array}$ & $\begin{array}{l}\text { Jánské } \\
\text { Lázně }\end{array}$ & $\begin{array}{l}\text { Nové } \\
\text { Město }\end{array}$ & $\begin{array}{l}\text { Nové } \\
\text { Město }\end{array}$ & Abrechtice & Nová Ves & Kokonín \\
\hline $\begin{array}{l}\text { Sampling } \\
\text { Date }\end{array}$ & & $\begin{array}{c}18 \\
\text { November } \\
2005\end{array}$ & $\begin{array}{c}18 \\
\text { Novem- } \\
\text { ber } \\
2005\end{array}$ & $\begin{array}{c}17 \\
\text { Novem- } \\
\text { ber } \\
2005\end{array}$ & $\begin{array}{c}11 \\
\text { Septem- } \\
\text { ber } \\
2009\end{array}$ & $\begin{array}{c}07 \\
\text { Septem- } \\
\text { ber } \\
2006\end{array}$ & $\begin{array}{c}29 \\
\text { Septem- } \\
\text { ber } \\
2011\end{array}$ & $\begin{array}{c}29 \\
\text { Septem- } \\
\text { ber } \\
2011\end{array}$ & $\begin{array}{c}21 \\
\text { Septem- } \\
\text { ber } \\
2013\end{array}$ & $\begin{array}{c}15 \text { July } \\
2017\end{array}$ & $\begin{array}{l}20 \text { June } \\
2015\end{array}$ \\
\hline Cations & value & & & & & & & & & & \\
\hline $\begin{array}{c}\mathrm{Li} \\
\mathrm{Na}\end{array}$ & $\begin{array}{l}(\mathrm{mg} / \mathrm{L}) \\
(\mathrm{mg} / \mathrm{L})\end{array}$ & $\begin{array}{c}\text { n.a. } \\
4.8\end{array}$ & $\begin{array}{c}\text { n.a. } \\
4\end{array}$ & $\begin{array}{l}\text { n.a. } \\
8.5\end{array}$ & $\begin{array}{l}\text { n.a. } \\
1.78\end{array}$ & $\begin{array}{c}\text { n.a. } \\
2.2\end{array}$ & $\begin{array}{l}\text { n.a. } \\
5.15\end{array}$ & $\begin{array}{l}\text { n.a. } \\
3.59\end{array}$ & $\begin{array}{l}\text { n.a. } \\
310\end{array}$ & $\begin{array}{c}\text { n.a. } \\
12.58\end{array}$ & $\begin{array}{c}0.015 \\
58\end{array}$ \\
\hline K & $(\mathrm{mg} / \mathrm{L})$ & 1.2 & 1.3 & 1.2 & 0.72 & 1.1 & 1.63 & 1.56 & 23.7 & 1.04 & 6.97 \\
\hline $\mathrm{NH}_{4}$ & $(\mathrm{mg} / \mathrm{L})$ & $<0.03$ & $<0.03$ & $<0.03$ & n.a. & $<0.03$ & n.a. & n.a. & n.a. & n.a. & n.a. \\
\hline $\mathrm{Mg}$ & $(\mathrm{mg} / \mathrm{L})$ & 1.2 & 0.9 & 1.4 & 2.83 & 1.2 & 2.80 & 2.12 & 35.9 & 3.16 & 6.82 \\
\hline $\mathrm{Ca}$ & $(\mathrm{mg} / \mathrm{L})$ & 5.8 & 5.8 & 9.8 & 11.2 & 6.00 & 11.4 & 7.14 & 108 & 45.5 & 31.1 \\
\hline $\mathrm{Sr}$ & (mg/L) & 0.018 & 0.020 & 0.017 & 0.035 & 0.008 & $<0.005$ & $<0.005$ & 0.46 & 0.05 & 0.14 \\
\hline $\mathrm{Ba}$ & (mg/L) & 0.003 & 0.002 & 0.002 & 0.028 & 0.008 & 0.009 & 0.018 & 0.270 & 0.012 & 0.056 \\
\hline $\mathrm{Fe}$ & $(\mathrm{mg} / \mathrm{L})$ & $<0.009$ & $<0.009$ & 0.25 & $<0.005$ & 0.020 & 0.028 & 0.019 & $<0.005$ & 0.058 & 0.056 \\
\hline Mn & $(\mathrm{mg} / \mathrm{L})$ & 0.003 & 0.003 & 0.019 & $<0.005$ & 0.041 & 0.005 & 0.059 & 2.8 & 0.003 & 0.443 \\
\hline $\mathrm{Al}$ & $(\mathrm{mg} / \mathrm{L})$ & 0.03 & 0.042 & 0.002 & $<0.05$ & 0.429 & 0.82 & 1.21 & 0.27 & 0.12 & 0.183 \\
\hline $\mathrm{Ti}$ & $(\mathrm{mg} / \mathrm{L})$ & 0.001 & 0.001 & 0.001 & $<0.005$ & 0.001 & $<0.01$ & $<0.01$ & 0.02 & n.a. & 0.001 \\
\hline \multicolumn{12}{|l|}{ Anions } \\
\hline F & $(\mathrm{mg} / \mathrm{L})$ & 0.12 & 0.11 & 0.54 & 0.065 & 0.28 & 1.81 & 1.36 & 0.33 & 0.36 & $<0.2$ \\
\hline $\mathrm{Cl}$ & $(\mathrm{mg} / \mathrm{L})$ & 1.0 & 0.8 & 5.9 & 1.23 & 0.8 & 2.72 & 3.04 & 785 & 5.4 & 136 \\
\hline $\mathrm{Br}$ & $(\mathrm{mg} / \mathrm{L})$ & n.a. & n.a. & n.a. & n.a. & n.a. & 0.009 & 0.007 & $<0.2$ & $<0.2$ & n.a. \\
\hline $\mathrm{SO}_{4}$ & $(\mathrm{mg} / \mathrm{L})$ & 11.9 & 11.5 & 2.5 & 13.6 & 10.4 & 39.4 & 31.0 & 45.8 & 35.2 & 39.5 \\
\hline $\mathrm{NO}_{2}$ & $(\mathrm{mg} / \mathrm{L})$ & $<0.01$ & $<0.01$ & $<0.01$ & n.a. & $<0.01$ & 0.002 & 0.002 & n.a. & n.a. & n.a. \\
\hline $\mathrm{NO}_{3}$ & $(\mathrm{mg} / \mathrm{L})$ & 5.3 & 6.0 & 24.0 & 1.86 & 1.4 & 3.98 & 3.22 & 20.2 & 16.9 & 43.2 \\
\hline $\mathrm{PO}_{4}$ & $(\mathrm{mg} / \mathrm{L})$ & 0.61 & 0.45 & $<0.01$ & $<0.2$ & $<0.01$ & n.a. & n.a. & $<0.4$ & $<0.4$ & n.a. \\
\hline $\mathrm{HCO}_{3}$ & $(\mathrm{mg} / \mathrm{L})$ & 18.0 & 9.2 & 28.0 & 48.8 & 13.4 & 48.8 & 25.9 & 4.6 & 18.3 & 18.3 \\
\hline \multicolumn{12}{|c|}{ Microelements } \\
\hline V & $(\mu \mathrm{g} / \mathrm{L})$ & 0.08 & 0.06 & 0.07 & n.a. & 0.1 & n.a. & n.a. & n.a. & n.a. & n.a. \\
\hline $\mathrm{Cr}$ & $(\mu \mathrm{g} / \mathrm{L})$ & 0.44 & 0.19 & $<0.01$ & n.a. & 0.13 & n.a. & n.a. & n.a. & n.a. & n.a. \\
\hline Co & $(\mu \mathrm{g} / \mathrm{L})$ & 0.022 & 0.011 & 0.015 & n.a. & 0.26 & n.a. & n.a. & n.a. & n.a. & 8 \\
\hline $\mathrm{Ni}$ & $(\mu \mathrm{g} / \mathrm{L})$ & 0.97 & 0.98 & 0.54 & n.a. & 0.72 & n.a. & n.a. & n.a. & n.a. & 8 \\
\hline $\mathrm{Cu}$ & $(\mu \mathrm{g} / \mathrm{L})$ & 1.16 & 0.32 & 0.98 & $<10$ & 1.17 & $<10$ & $<10$ & $<10$ & n.a. & 69 \\
\hline $\mathrm{Zn}$ & $(\mu \mathrm{g} / \mathrm{L})$ & 20 & 14.6 & 57 & $<5$ & 27.7 & $<5$ & $<5$ & 90 & n.a. & 148 \\
\hline As & $(\mu \mathrm{g} / \mathrm{L})$ & 4.2 & 4.4 & 18.1 & n.a. & 24.5 & n.a. & n.a. & n.a. & n.a. & $<68$ \\
\hline $\mathrm{Ag}$ & $(\mu \mathrm{g} / \mathrm{L})$ & 0.045 & 0.034 & $<0.005$ & n.a. & 0.035 & n.a. & n.a. & n.a. & n.a. & n.a. \\
\hline $\mathrm{Cd}$ & $(\mu \mathrm{g} / \mathrm{L})$ & 0.36 & 0.29 & 0.69 & n.a. & 0.28 & n.a. & n.a. & n.a. & n.a. & n.a. \\
\hline $\mathrm{Pb}$ & $(\mu \mathrm{g} / \mathrm{L})$ & 0.39 & 0.89 & 0.36 & 0.22 & 0.48 & $<50$ & $<50$ & $<30$ & n.a. & n.a. \\
\hline $\mathrm{Bi}$ & $(\mu \mathrm{g} / \mathrm{L})$ & $<0.005$ & $<0.005$ & 0.23 & n.a. & $<0.005$ & n.a. & n.a. & n.a. & n.a. & n.a. \\
\hline $\begin{array}{c}\text { Undissoc. } \\
\mathrm{H}_{4} \mathrm{SiO}_{4}\end{array}$ & $(\mathrm{mg} / \mathrm{L})$ & n.a. & n.a. & n.a. & 17.2 & n.a. & 36.5 & 26.1 & 24.6 & n.a. & 19.8 \\
\hline $\begin{array}{l}\text { Total } \\
\text { Mineral- } \\
\text { ization }\end{array}$ & $(\mathrm{mg} / \mathrm{L})$ & 50.0 & 40.1 & 82.1 & 99.4 & 37.3 & 155.1 & 106.3 & 1361.9 & 138.7 & 360.6 \\
\hline \multicolumn{12}{|l|}{ Radiology } \\
\hline Th & $(\mu \mathrm{g} / \mathrm{L})$ & 0.15 & 0.14 & 0.08 & $<0.01$ & 0.20 & 0.016 & 0.015 & n.a. & n.a. & n.a. \\
\hline $\mathrm{U}$ & $(\mu \mathrm{g} / \mathrm{L})$ & 1.38 & 1.48 & 1.36 & 16.6 & 9.09 & 3.97 & 2.68 & 0.96 & n.a. & 4.45 \\
\hline${ }^{226} \mathrm{Ra}$ & $(\mathrm{Bq} / \mathrm{L})$ & 0.078 & 0.024 & 0.017 & 0.09 & n.a. & 0.12 & 0.19 & 1.69 & 0.11 & 0.47 \\
\hline${ }^{222} \mathrm{Rn}$ & $(\mathrm{Bq} / \mathrm{L})$ & 2243 & 2185 & 4485 & 3330 & 4500 & 5723 & 3215 & 1750 & 2672 & 2420 \\
\hline $\begin{array}{c}\text { Eh } \\
(\mathrm{ORP})_{\mathrm{H}}\end{array}$ & $(\mathrm{mV})$ & 427 & 461 & 238 & 545 & 481 & 556 & 519 & 495 & 501 & 480 \\
\hline $\begin{array}{l}\text { Dissolved } \\
\mathrm{CO}_{2}\end{array}$ & $(\mathrm{mg} / \mathrm{L})$ & 18.0 & 19.8 & 11.4 & n.a. & 4.4 & n.a. & n.a. & n.a. & n.a. & n.a. \\
\hline
\end{tabular}

\section{References}

1. Sheen, S.; Lee, K.S.; Chung, W.Y.; Nam, S.; Kang, D.R. An updated rewiew of case-control studies of lung cancer and indoor radon-Is indoor radon the risk factor for lung cancer? Ann. Occup. Environ. Med. 2016, 28, 1-9.

2. Rodriguez-Martinez, Á.; Torres-Durán, M.; Barros-Dios, J.M.; Ruano-Ravina, A. Residental radon and small cell lung cancer. A systematic review. Cancer Lett. 2018, 426, 57-62. [CrossRef] [PubMed]

3. IARC 2012-Radiation. A Review of Human Carcinogens. IARC Monographs on the Evaluation of Carcinogenic Risks to Humans. International Agency for Research on Cancer; World Health Organization: Lyon, France, 2012; Volume 100D.

4. Dobrzyński, L.; Fornalski, K.W.; Reszcyńska, J. Meta-analysis of thirty-two case-control and two ecological radon studies of lung cancer. J. Radiat. Res. 2017, 59, 149-163. [CrossRef] [PubMed]

5. $\quad$ Orient, J.M. Fukushima and Reflections on Radiation as a Terror Weapon. J. Amer. Phys. Surg. 2017, 19, 48-55. 
6. György, C. Hormesis and immunity: A review. A. Microbiol. Immunol Hungar. 2018, 66, 155-168.

7. Becker, K. One century of radon therapy. Int. J. Low Radiat. 2004, 1, 334-357. [CrossRef]

8. Przylibski, T.A. Radon: A radioactive therapeutic element. In Radon, Health and Natural Hazards; Gilmore, G.K., Perrier, F.E., Crockett, R.G.M., Eds.; The Geological Society of London, Special Publication 451: London, UK, 2018; pp. $209-236$.

9. Deetjen, P.; Falkenbach, A.; Harder, D.; Jöckel, H.; Kaul, A.; Philipsborn, H.V. Radon als Heilmittel. Terapeutische Wirksamkeit, Biologischer Wirkungsmechanismus und Vergleichende Risikobewertung; Verlag Dr. Kovac: Heidelberg, Germany, 2005; 111p.

10. Cucu, A.; Shreder, K.; Kraft, D.; Rühle, P.F.; Klein, G.; Thiel, G.; Frey, B.; Gaipl, U.S.; Fournier, C. Decrease of markers related to bone erosion in serum of patients with mucosceletal disorders after serial low-dose radon spa therapy. Front. Immunol. 2017, 8, 822. [CrossRef]

11. Rühle, P.F.; Wunderlich, R.; Deloch, L.; Fournier, C.; Maier, A.; Klein, G.; Fietkau, R.; Gaipl, U.S.; Frey, B. Modulation of the peripheral immune system after low-dose radon spa therapy: Detailed longitudinal immune monitoring of patients within the RAD-ON01. Autoimunity 2017, 50, 133-140. [CrossRef]

12. Vogiannis, E.; Nikolopoulos, D.; Louizi, A.; Halvadakis, C.P. Radon variations during treatment in thermal spas of Lesvos Island (Greece). J. Environ. Radioact. 2004, 75, 159-170. [CrossRef]

13. Voronov, A.N. Radon-rich waters in Russia. Environ. Geol. 2004, 46, 630-634. [CrossRef]

14. Zdrojewicz, Z.; Strzelczyk, J. Radon treatment controversy. Dose-Response 2006, 4, 106-118. [CrossRef]

15. Erickson, B.E. The therapeutic use of radon: A biomedical treatment in Europe; An "alternative" remedy in the United States. Dose-Response 2007, 5, 48-62. [CrossRef]

16. Nagy, K.; Kávási, N.; Kovács, T.; Somlai, J. Radon therapy and speleotherapy in Hungary. Presse Therm. Clim. 2008, 145, $219-225$.

17. Persianova-Dubrova, A.L.; Badalov, N.G.; Lvova, N.V.; Tupitsyna, I.U.; Uianaeva, A.I.; Krikorova, S.A.; Adilov, V.B.; Linok, V.A.; Povazhnaia, E.L. Crenobalneotherapy in Russia. Presse Therm. Clim. 2012, 149, 93-102.

18. Kröner, A.; Jaeckel, P.; Hegner, E.; Opletal, M. Single zircon ages and whole-rock Nd isotopic sustematics of early Palaeozoic granitoid gneisses from the Czech nad Polish Sudetes (Jizerské hory, Krkonoše Mountains and Orlice-Sněžník Complex). Int. J. Earth Sci. 2001, 90, 304-324. [CrossRef]

19. Oberc-Dziedzic, T.; Kryza, R.; Pin, C.; Mochnacka, K.; Larionov, A. The orthogneiss and schist complex of the Karkonosze-Izera Massif (Sudetes, SW Poland): U-Pb SHRIMP zircon ages, Nd-isotope systematics and protoliths. Geol. Sudet. 2009, 41, 3-24.

20. Jeřábek, P.; Konopásek, J.; Žáčková, E. Two-stage exhumation of subducted Saxothuringian continental crust records underplating in the subduction channel and collisional forced folding (Krkonoše-Jizera Mts., Bohemian Massif). J. Struct. Geol. 2016, 89, 214-229. [CrossRef]

21. Oberc-Dziedzic, T.; Kryza, R.; Mochnacka, K.; Larionov, A. Ordovician passive continental margin magmatism in the CentralEuropean Variscides: U-Pb zircon data from the SE part of the Karkonosze-Izera Massif, Sudetes, SW Poland. Int. J. Earth Sci. 2010, 99, 27-46. [CrossRef]

22. Winchester, J.A.; Patočka, F.; Kachlík, V.; Melzer, M.; Nawakowski, C.; Crowley, Q.G.; Floyd, P.A. Geochemical discrimination of metasedimentary sequences in the Krkonoše-Jizera terrane (West Sudetes, Bohemian Massif): Paleotectonic and stratigraphic constraints. Geol. Carpat. 2003, 54, 267-280.

23. Žák, J.; Verner, K.; Sláma, J.; Kachlík, V.; Chlupáčová, M. Multistage magma emplacement and progressive strain accumulation in the shallow-level Krkonoše-Jizera plutonic complex, Bohemian Massif. Tectonics 2013, 32, 1493-1512. [CrossRef]

24. Černík, T.; Goliáš, V. Radioactivity of granitoids the Krkonoše-Jizera pluton: Statistical evaluation of archive data. In Geoscience Research Reports for 2013/D-Mineralogy, Petrology and Geochemistry; Czech Geological Survey: Prague, Czech Republic, 2014; pp. 97-100. (In Czech)

25. Abraham, M.; Dudek, A.; Fediuk, F. The Czech part of the Krkonoše-Jizera Mts. Pluton in the light of regional heavy mineral prospecting. Bull. Geosci. 2000, 75, 17-22.

26. Vrána, S.; Sulovský, P.; Schovánek, P. Changes in chemical composition of allanite-(Ce) accompanying alteration: Relations with uranium release in biotite monzogranite near Bedřichov. In Geoscience Research Reports for 2011; Czech Geological Survey: Prague, Czech Republic, 2012; pp. 202-207. (In Czech)

27. Veselý, T. Small uranium deposits of crystalline of the Bohemian Massif. Part III: North and northwest Bohemian area. Geol. Hydometal. Uranium 1982, 6, 3-46. (In Czech)

28. Mochnacka, K.; Banaś, M. Occurence and genetic relationships of uranium and thorium mineralization in the Karkonosze Izera Block (the Sudety Mts., SW Poland). Ann. Soc. Geol. Polon. 2000, 70, 137-150.

29. Mochnacka, K.; Oberc-Dziedzic, T.; Mayer, W.; Pieczka, A. Ore mineralization related to geological evolution of the KarkonoszeJizera Massif (the Sudetes, Poland)—Towards a model. Ore Geol. Rew. 2015, 64, 215-238. [CrossRef]

30. Goliáš, V.; Tumurkhuu, G.; Kohn, P.; Šálek, O.; Plášil, J.; Škoda, R.; Soumar, J. Construction of new houses on a uranium vein outcrop: A case study from the Czech Republic. Nukleonika 2016, 61, 343-349. [CrossRef]

31. Przylibski, T.A.; Mamont-Cieśla, K.; Kusyk, M.; Dorda, J.; Kozlowska, B. Radon concentrations in groundwaters of the Polish part of the Sudety Mountains (SW Poland). J. Environ. Radioact. 2004, 75, 193-209. [CrossRef]

32. Krásný, J. Groundwaters of the Czech Republic; Czech Geological Survey: Prague, Czech Republic, 2012; 1143p, ISBN 978-80-7075797-0. (In Czech)

33. Act No. 164/2001 Sb., §2 (1), “Spa Act”of the Czech Collection of Laws. Available online: https://www.zakonyprolidi.cz/cs/20 01-164 (accessed on 10 November 2021). 
34. Ustawa z dnia 9 czerwca 2011 r. Prawo geologiczne i górnicze (Mining and Geological Law). Dz.U. z 2011 r. nr 163, poz. 981, art. 5, ust. 2. Available online: http:/ / isap.sejm.gov.pl/isap.nsf/DocDetails.xsp?id=wdu20111630981 (accessed on 11 November 2021).

35. Tokarev, A.N.; Schebakov, A.B. Radiogidrogeologia; Gosgeoltechnizdat: Moscow, Russia, 1956; 263p. (In Russian)

36. IAEA 2003: Guidelines for Radioelement Mapping Using Gamma Ray Spectrometry Data; International Atomic Energy Agency: Vienna, Austria, 2003; 173p.

37. IAEA 2010: Radioelement Mapping: Basic Principles, Objectives, Guides; Technical Reports; International Atomic Energy Agency: Vienna, Austria, 2010; 123p.

38. Hynie, O. Hydrogeology of the Czechoslovakia, Part II. Mineral Waters; Academia: Prague, Czech Republic, 1963; 797p.

39. Jetel, J.; Rybářová, L. Mineral Waters of the East Bohemian Region; Czech Geological Survey: Prague, Czech Republic, 1979; 228p. (In Czech)

40. Kačura, G. Mineral Waters of the North Bohemian Region; Czech Geological Survey: Prague, Czech Republic, 1980; 178p. (In Czech)

41. Jaiswal, R.K.; Mukherjee, S.; Krishnamurthy, J.; Saxena, R. Role of remote sensing and GIS techniques for generation of groundwater prospect zones towards rural development: An approach. Int. J. Remote Sens. 2003, 24, 993-1008. [CrossRef]

42. Teixeira, J.; Chaminé, H.I.; Carvalho, J.M.; Pérez-Alberto, A.; Rocha, F. Hydrogeomorphological mapping as a tool in grounwater exploration. J. Maps 2013, 9, 263-273. [CrossRef]

43. Krištiak, J.; Záliš, Z. Database of Radioactive Object of the Uranium Survey for Environmental Purposes, Průzkum Přibram—GEOFOND: Příbram, Czech Republic, 1993; 97p, (Unpublished). (In Czech)

44. Kadlčíková, E. Geological Structure and Prospects of Uranium Distribution in the West Sudeten Region; MS. Czechoslovak Uranium Industry: Liberec, Czech Republic, 1975; 199p. (In Czech)

45. Stárková, Z.; Zrůstek, V. Prognoses of ČSSR for Uranium, Area No. 44-Orlice-Kłodzko Dome; MS. Czechoslovak Uranium Industry: Dolní Rožínka, Czech Republic, 1976; 197p. (In Czech)

46. Sedlák, J.; Gnojek, I.; Dědáček, K.; Zabadal, S. Airborne Geophysical Mapping of Radioactive Contamination in the Liberec Region; Final Report; MS. Miligal Company, Brno, GEOFOND: Prague, Czech Republic, 2005.

47. Lysenko, V.; Mrázová, Š.; Mannová, M. Morphotectonic Analysis of the Jizera Mountain Protected Landscape Area; Final Report; Czech Geological Survey: Prague, Czech Republic, 2003; 28p. (In Czech)

48. Mareš, S. Introduction to Applied Geophysics; D. Reidel Publishing Company: Dordrecht, The Netherlands; Boston, MA, USA; Lancaster, PA, USA, 1984; 510p.

49. IAEA 1976: Radiometric Reporting Methods and Calibration in Uranium Exploration; International Atomic Energy Agency: Vienna, Austria, 1976; 57p.

50. IAEA 1989: Construction and Use of Calibration Facilities for Radiometric Field Equipment; International Atomic Energy Agency: Vienna, Austria, 1989; 86p.

51. Matolín, M. Determination of 222Rn and 220Rn by Portable Emanometers. Acta Univ. Carol. Geol. 1988, 1, 101-110.

52. Haaslahti, J.; Aalto, J.; Oikari, T. A portable liquid scintillation counter for general LSC and high sensitivity alpha-counting applications. J. Radioanal. Nucl. Chem. 2000, 243, 377-381. [CrossRef]

53. Pates, J.M.; Mullinger, N.J. Determination of $222 \mathrm{Rn}$ in fresh water: Development of a robust method of analysis by $\alpha / \beta$ separation liquid scintillation spectrometry. Appl. Radiat. Isot. 2007, 65, 92-103. [CrossRef]

54. Manová, M.; Matolín, M. Radiometric Map of the Czech Republic 1:500,000; Czech Geological Survey: Prague, Czech Republic, 1995.

55. Hocking, R.R. Methods and Applications of Linear Models: Regression and Analysis of Variance; John Wiley: New York, NY, USA, 1996.

56. Eisenhauer, J.G. Regression through the Origin. Teach. Stat. 2003, 25, 3. [CrossRef]

57. Valečka, J. Sedimentology of upper Cretaceous in the Kłodzko graben. Sborn. Geol. Věd Ser. Geol. 1988, 43, 147-191. (In Czech)

58. Holluta, J. Über radioaktive Quellen in der Sudeten. HDI-Mitt. Huptvereines Dtsch. Ing. Tschechosl. Rep. 1929, 18, 66-215.

59. Lipanský, T. The Springs of the Radioactive Mineral Waters in the Orlice-Sněžník Dome. Master's Thesis, Faculty of Science, Charles University, Prague, Czech Republic, 2007; 76p. (In Czech).

60. Wagner, A. Radioaktivität der Quellen im Sudetenland. Firgenwald 1942, 13, 94-111.

61. Goliáš, V. Springs of the radioactive medicinal groundwaters in Janské Lázně-Těsný důl. Opera Corcon. 2007, 44, 161-169. (In Czech)

62. Goliáš, V.; Przylibski, T.A.; Lipanský, T.; Dohnal, J.; Miśta, W.; Nowakowski, R.; Tejnecký, V.; Mokrá, Z.; Vávrová, J.; Šimon, J.; et al. Springs of the radioactive mineral groundwaters in the Kowary-Horní Malá Úpa area. Opera Corcon. 2010, 47 (Suppl. 1), 75-90. (In Czech)

63. Miśta, W.; Nowakowski, R. Investigation of radon water in old workings after uranium mining in Kowary. In Dzieje górnictwaelement europejskiego dziedzictwa kultury; Zagożdżon, P.P., Madziarz, M., Eds.; Oficyna Wydawnicza Politechniki Wrocławskiej: Wrocław, Poland, 2009; pp. 245-253.

64. Markov, I.; Savolis, V.; Knjazev, A.; Gromkov, L. Calculation of Reserves of the Jáchymov Mines Company in 1952; MS-Archive of the DIAMO State Enterprise: Jáchymov, Czechoslovakia, 1953. (In Russian)

65. Nývlt, D.; Engel, Z.; Tyráček, J. Pleistocene Glaciations of Czechia. Dev. Quternary Sci. 2011, 15, 37-46.

66. Przylibski, T.A. Radon, a Component of Healing Waters of the Sudetes; Oficina Wydawiczna Politechniki Wrocławskiej: Wrocław, Poland, 2005; 329p. (In Polish) 
67. Hrušková, L. Springs of the Radioactive Mineral Waters in the Lázně Libverda—Świeradów-Zdrój Area. Master's Thesis, Faculty of Science, Charles University, Prague, Czech Republic, 2013; 68p. (In Czech).

68. Goliáš, V.; Hrušková, L.; Przylibski, T.A.; Lipanský, T.; Černík, T. Radioactive springs of the Krkonoše Mts and Jizera Mts as geological phenomena, healing sources and tourist attractions. Opera Corcon. 2013, 50, 135-142.

69. Černík, T. Springs of the Radioactive Mineral Waters in the Chrastava-Bogatynia Area. Master's Thesis, Faculty of Science, Charles University, Prague, Czech Republic, 2017; 63p. (In Czech).

70. Goliáš, V.; Hrušková, L.; Černík, T.; Bruthans, J.; Nakládal, P.; Churáčková, Z.; Kula, A. Albrechtice chloride district. In Geoscience Research Reports for 2013/H_Hydrogeology; Czech Geological Survey: Prague, Czech Republic, 2014; pp. 159-164. (In Czech)

71. Kopecký, L. České středohoři Mts and Ambient Young Alkaline Volcanic Complexes in the Ohře Rift, Czech Republic: Volcanology, Petrology and Rift Evolution; Czech Geological Survey: Prague, Czech Republic, 2010; 188p, ISBN 978-80-7075-748-2.

72. Bruthans, J. Delay Time and the Water Chemistry in the Zittau Basin, Unpublished Report; Charles University: Prague, Czech Republic, 2008; 20p. (In Czech)

73. Porcelli, D.; Swarzenski, P.W. The Behavior of U- and Th-series Nuclides in Groundwater. Rev. Mineral. Geochem. 2003, 52, 317-361. [CrossRef]

74. Thurnquist, E.L. Regional increase of mean chloride concentration in water due to the application of deicing salt. Sci. Total Environ. 2004, 325, 29-37.

75. Kändler, M.; Blechinger, K.; Seidler, C.H.; Pavlů, V.; Šanda, M.; Dostál, T.; Krása, J.; Vitvar, T.; Štich, M. Impact of land use on water quality in the upper Nisa catchment in the Czech Republic and Germany. Sci. Total Environ. 2017, 586, 1316-1325. [CrossRef]

76. Kohn, P. Springs of the Radioactive Mineral Waters on Tanvald Granite. Master's Thesis, Faculty of Science, Charles University, Prague, Czech Republic, 2015; p. 34. (In Czech).

77. Klomínský, J.; Jarchovský, T.; Rajpoot, G.S. Atlas of Plutonic Rocks and Orthogneisses in the Bohemian Massif. 4. LUGICUM; Czech Geological Survey: Prague, Czech Republic, 2010; 78p.

78. Barnet, I. The Maps of Radon Index of the Geological Basement 1:50,000; Czech Geological Survey Press: Prague, Czech Republic, 2005.

79. Barnet, I.; Pacherová, P.; Preusse, W.; Stec, B. Cross-border radon index map 1:100,000 Lausitz-Jizera-Karkonosze Region (northern part of the Bohemian Massif). J. Environ. Radioact. 2010, 101, 809-812. [CrossRef]

80. Khan, A.R.; Rafique, M.; Rahman, S.U.; Basharat, M.; Shahzadi, C.; Ahmed, I. Geo-spatial analysis of radon in spring and well water using kriging interpolation method. Water Supply 2018, 19, 222-235. [CrossRef]

81. Szegvary, T.; Leunberger, M.C.; Conen, F. Predicting terestrial 222Rn flux using gamma dose rate as a proxy. Atmos. Chem. Phys 2007, 7, 2789-2795. [CrossRef]

82. Barbosa, S.; Huisman, J.A.; Azevedo, E.B. Meteorological and soil surface effects in gamma radiation time series-Implications for assessment of earthquake precursors. J. Environ. Radiact. 2018, 195, 72-78. [CrossRef]

83. Li, P.; Zhang, R.; Gu, M.; Zheng, G. Uptake of the natural radioactive gas radon by an epiphytic plant. Sci. If Tonatal Environ. 2018, 612, 436-441. [CrossRef]

84. Li, P.; Sun, X.; Cheng, J.; Zheng, G. Absorbtion of the natural radioactive gas 222Rn and its progeny $210 \mathrm{~Pb}$ by Spanish moss Tillandsia usneoides and its response to radiation. Environ. Exp. Bot. 2019, 158, 22-27. [CrossRef]

85. Przylibski, T.A. Shallow circulation groundwater-The main type of water containing hazardous radon concentration. Nat. Hazards Earth Syst. Sci. 2011, 11, 1695-1703. [CrossRef]

86. Banks, D.; Robins, N. An introduction to Grounwater in Crystalline Bedrock; Norges Geologiske Undersokelse: Tronheim, Norway, $2002 ; 68$ p.

87. Khaska, M.; Salle, C.L.; Videau, G.; Flinois, J.S.; Frape, S.; Team, A.; Verdoux, P. Deep water circulation at the northern Pyrenean thrust: Implication of high temperature water-rock interaction process on the mineralization of major spring water in an overthrust area. Chemical Geol. 2015, 419, 114-131. [CrossRef]

88. Wood, W.W.; Kraemer, T.F.; Shapiro, A. Radon $\left({ }^{222} \mathrm{Rn}\right)$ in Ground Water of Fractured Rocks: A Diffusion/Ion Exchange Model. Ground Water 2004, 42, 552-567. [CrossRef] [PubMed]

89. Gainon, F.; Goldschneider, N.; Surbeck, H. Conceptual model for the origin of high radon levels in spring waters-The example of the St. Placidus spring, Grisons, Swiss Alps. Swiss J. Geosci 2007, 100, 251-262. [CrossRef] 